\author{
Irena Merc ${ }^{1}$ \\ Višja pravosodna svetovalka na Okrajnem sodišču v Mariboru
}

\title{
PRIMERNOST IZVRŠILNEGA NASLOVA ZA IZVRŠBO
}

UDK: 497.952 (497.4)

DOI: $10.31141 /$ zrpfs.2021.58.141.989

Izvorni znanstveni rad

Primljeno: 1. srpnja 2021.

Primernost izvršilnega naslova za izvršbo je materialna predpostavka za dovolitev izvršbe. Obveznost, ki jo upnik izterjuje, mora biti določena ali določljiva, sicer izvršbe ni mogoče dovoliti. Določljivost obveznosti pomeni, da morajo vsi podatki, na podlagi katerih je obveznost mogoče določiti, že izhajati iz samega izreka sodne odločbe oziroma iz drugega izvršilnega naslova. Izvršilno sodišče ne sme samo pomensko določati obveznosti iz izvršilnega naslova. Predvsem pri nedenarnih obveznostih je pomembno, da so lete jasno določene ter da ne puščajo dvomov o tem, kaj je treba storiti, da bo obveznost izpolnjena. Kadar upnik predlaga izvršbo na podlagi tujega izvršilnega naslova, je izvršilno sodišče v skladu z načelom formalne legalitete vezano na tuj izvršilni naslov, vendar pa mora enako kot pri domačih izvršilnih naslovih presojati, ali je tuj izvršilni naslov primeren za izvršbo.

Ključne besede: izvršilni postopek $v$ Republiki Sloveniji, primernost izvršilnega naslova, načelo formalne legalitete, določnost zahtevka, določljiva obveznost, tuj izvršilni naslov

\section{UVOD}

Prvi odstavek 21. člena Zakona o izvršbi in zavarovanju ${ }^{2}$ določa: »Izvršilni naslov je primeren za izvršbo, če so v njem navedeni upnik in dolžnik ter predmet, vrsta, obseg in čas izpolnitve obveznosti. « Presojo primernosti izvršilnega naslova opravi izvršilno sodišče že ob dovolitvi izvršbe. Sodišče mora presoditi, ali izvršilni naslov vsebuje ustrezno opredelitev terjatve, ki naj se izvrši. Terjatev mora biti določena subjektivno, tj. z natančno opredelitvijo strank, ${ }^{3} \mathrm{ki}$ jim pripada pravica

\footnotetext{
1 Irena Merc, Višja pravosodna svetovalka na Okrajnem sodišču v Mariboru, e-mail: merc.irena@ gmail.com

2 V nadaljevanju ZIZ (Uradni list RS, št. 51/98, 11/99 - odl. US, 89/99 - ZPPLPS, 11/01 - ZRacS-1, 75/02, 87/02 - SPZ, 70/03 - odl. US, 16/04, 132/04 - odl. US, 46/05 - odl. US, 96/05 - odl. US, 17/06, 30/06 - odl. US, 69/06, 115/06, 67/07 - ZS-G, 93/07, 37/08 - ZST-1, 45/08 - ZArbit, 28/09, 51/10, 26/11, 14/12, 17/13 - odl. US, 45/14 - odl. US, 53/14, 58/14 - odl. US, 50/15, 54/15, 76/15 - odl. US, 11/18, 53/19 - odl. US, 66/19 - ZDavP-2M, 23/20 - SPZ-B, 49/20 - ZIUZEOP, 61/20 - ZIUZEOP-A, 203/20 - ZIUPOPDVE, $13 / 21,36 / 21)$

3 O pomembnosti označitve strank glej (Volk 2000, str. 68-69).
} 
ali jih bremeni obveznost, in objektivno, tj. z natančno opredelitvijo obveznosti (navedba predmeta, vrste, obsega in časa izpolnitve obveznosti). ${ }^{4}$

Vsebinska presoja primernosti izvršilnega naslova za izvršbo je ena izmed bistvenih materialnih predpostavk za dovolitev izvršbe. Materialne predpostavke izvršbe so pogoj za utemeljenost zahteve upnika za pravno varstvo v izvršilnem postopku. Ce sodišče ugotovi, da izvršilni naslov, ni primeren za izvršbo, predlog za izvršbo zavrne. Zaradi neobstoja formalnih predpostavk pa sodišče predlog za izvršbo zavrže. ${ }^{5}$

Izvršba je zakonita in dopustna, dokler se opira na obstoječ izvršilni naslov. ${ }^{6}$ Izvršilno sodišče v zvezi z izvršilnim naslovom ne preizkuša terjatve, o kateri je bilo že pravnomočno odločeno, mora pa preizkusiti, ali je terjatev, ki je v izvršilnem naslovu vsebovana, takšna, da jo bo mogoče izvršiti. Govorimo o preizkusu primernosti izvršilnega naslova za izvršbo. Če izvršilni naslov ne vsebuje dovolj natančne opredelitve terjatve, takega izvršilnega naslova ni mogoče šteti kot primernega za izvršbo, zato ga mora sodišče, ko odloča o predlogu za izvršbo kot neprimernega za izvršbo zavrniti. Neprimeren za izvršbo je izvršilni naslov takrat, kadar ne vsebuje dovolj določno opredeljene terjatve.

Elementi, ki so nujni, da lahko v izvršilnem postopku predloženo listino štejemo za primeren izvršilni naslov, so načeloma določeni v izreku sodne odločbe oziroma v tistem delu, ki dolžniku nalaga obveznost, ter morajo biti v skladu s pravili o objektivnih mejah pravnomočnosti. ${ }^{7}$ Če v izvršilnem naslovu ni določen rok za prostovoljno izpolnitev obveznosti, ga v skladu z drugim odstavkom 21. člena ZIZ določi sodišče v sklepu o izvršbi.

Na obstoj in primernost izvršilnega naslova za dovolitev izvršbe pazi izvršilno sodišče po uradni dolžnosti. ${ }^{8}$ Pred novelo ZIZ-L ${ }^{9}$ je veljalo, da načeloma opravi preizkus primernosti izvršilnega naslova sodišče že v dovolitveni fazi izvršbe, vendar pa tega preizkusa ni moglo opraviti, če upnik izvršilnega naslova predlogu za izvršbo ni priložil. V takem primeru, v kolikor sodišče ni dvomilo v obseg upnikove terjatve, je dovolilo izvršbo in se je s primernostjo izvršilnega naslova ukvarjalo šele ob odločanju o ugovoru dolžnika. Ce dolžnik ugovora zoper sklep o izvršbi ni vložil, pa se sodišče s primernostjo izvršilnega naslova sploh ni ukvarjalo. Primernosti izvršilnega naslova namreč ni več mogoče presojati, ko postane sklep o izvršbi pravnomočen. ${ }^{10}$ Po 25. 3. 2019 velja zakonska ureditev, da je treba predlogu za izvršbo vedno priložiti izvršilni naslov. Zato do takšnih situacij ne bo več prišlo, saj bo sodišče ob dovolitvi izvršbe moralo tudi preizkusiti, ali je izvršilni naslov primeren za izvršbo. S tem ko sodišče dovoli izvršbo, se jasno

4 (Rijavec 2003, str. 111-112).

5 O pomenu razlikovanja med vrstami predpostavk glej (Rijavec 2003, str. 101-103).

6 (Sajovic 1944, str. 119).

(Triva, Belajec, and Dika 1984, str. 140).

VSM sklep I Ip 425/2015 z dne 23. 9. 2015.

Uradni list RS, št. 11/2018.

10 VSC sklep Cp 735/2000 z dne 10. 1. 2001. 
opredeli tudi glede primernosti izvršilnega naslova. Če sodišče dovoli izvršbo in kasneje (po pravnomočnosti sklepa o izvršbi) ugotovi, da obveznost vsebovana $\mathrm{v}$ izvršilnem naslovu ni dovolj določno opredeljena, ne more več presojati primernosti izvršilnega naslova, temveč mora nadaljevati z izvršbo. ${ }^{11}$ Dovolilna faza je zato zelo pomembna, saj po pravnomočnosti sklepa o izvršbi ni več mogoče popraviti morebitne napake storjene ob dovolitvi izvršbe. ${ }^{12}$ Zaključimo lahko, da je presoja primernosti izvršilnega naslova bistvena za nemoten potek izvršbe in da mora primernost izvršilnega naslova glede na veljavno zakonsko ureditev sodišče nujno presojati $v$ fazi dovolitve izvršbe.

Enako kot slovenski ZIZ tudi hrvaški hrOZ ${ }^{13}$ v prvem odstavku 29. člena določa, da je izvršilna listina primerna za izvršbo, če so v njej označeni upnik in dolžnik ter predmet, vrsta, obseg in čas izpolnitve obveznosti. ${ }^{14}$ Dika poudarja, da mora biti terjatev v skladu $\mathrm{z}$ načelom stroge formalne legalitete definirana v subjektivnem, objektivnem in časovnem smislu. ${ }^{15}$ Terjatev se lahko dokazuje samo z izvršilno listino, glede njenih posameznih elementov pa tudi $z$ javno ali po zakonu overjeno listino oziroma s pravnomočno odločbo izdano v pravdnem postopku. Zato je obstoj izvršilne listine z določeno vsebino nujna predpostavka za dopustnost izvršbe. Tista listina, ki nima določene vsebine, tako ni primerna za izvršbo in zato tudi ne more biti veljavna podlaga za dovolitev izvršbe. ${ }^{16}$

Že Izvršilni postopnik iz leta $1930^{17}$ je določal pogoje, kdaj se sme izvršba dovoliti. Prvi odstavek § 12 IP je določal: »Izvršba se sme dovoliti samo, če so označeni v izvršilnem naslovu ne le upravičenec in zavezanec, ampak tudi predmet, vrsta, obseg in čas dolžne dajatve ali storitve ali dolžne opustitve.« Vidimo lahko, da je navedena vsebina zelo podobna današnji vsebini 21. člena ZIZ in 29. člena hrOZ, z izjemo, da ne vsebuje termina »primernost za izvršbo«, temveč »izvršba se sme dovoliti«. Poimenovanje »primernost izvršilnega naslova za izvršbo « je uvedel Zakon o izvršilnem postopku iz leta $1978^{18}$ in je danes že uveljavljen termin v slovenskem pravnem redu oziroma na hrvaškem »podobnost ovršne isprave za ovrhu ${ }^{19}$

11 Prav tam.

12 (Orož 2010, str. 91).

13 Hrvaški Ovršni zakon (Narodne novine 112/12, 25/13, 93/14, 55/16, 73/17, 131/20).

14 Prvi odstavek 29. člena hrOZ: »Ovršna isprava podobna je za ovrhu ako su u njoj naznačeni vjerovnik i dužnik te predmet, vrsta, opseg i vrijeme ispunjenja obveze."

15 (Dika 2007, str. 234-235).

16 (Dika 2007, str. 235) in (Triva, Belajec, and Dika 1984, str. 140).

17 Zakon o izvršbi in zavarovanju (izvršilni postopnik, v nadaljevanju IP) z dne 9. julija 1930, ki je bil razglašen v »Službenih novinah Kraljevine Jugoslavije« z dne 23. julija 1930, št. 165/LXII/364.

18 V nadaljevanju ZIP, Uradni list SFRJ, št. 20/78, 6/82, 74/87, 57/89, 83/89, 20/90, 27/90, Uradni list RS/I, št. 17/91 - ZUDE, Uradni list RS, št. 55/92 - ZVDK, 1/94 - odl. US, 51/98 - ZIZ, 72/98 - skl. US, $11 / 99$ - odl. US, 32/00. Glej 20. člen ZIP.

19 Glej naslov 29. člena hrOZ. 
V Republiki Avstriji je izvršilni postopek urejen v Izvršilnem redu Exekutionsordnung (EO), sprejetem leta $1896 .{ }^{20}$ Vsebina prvega odstavka $\S 7$ $\mathrm{EO}^{21}$ je enaka vsebini $\S 12$ IP z izjemo z novelo iz leta $1994^{22}$ vrinjenega stavka » primeru $\S 308 \mathrm{a} / 5 \mathrm{v}$ povezavi z odločitvijo po $\S 292 \ll$. Tudi avstrijski EO torej določa, kdaj se sme izvršba dovoliti, in ne uporablja termina »primernost izvršilnega naslova za izvršbo «. Ne glede na uporabo termina pa je vsem trem pravnim redom (slovenskemu, hrvaškemu in avstrijskemu) skupno, da je ob dovolitvi izvršbe treba presojati ali je zahtevek vsebovan $\mathbf{v}$ izvršilnem naslovu dovolj določen.

\section{PROBLEMATIKA DOMAČIH IZVRŠILNIH NASLOVOV}

Z vprašanjem primernosti izvršilnega naslova za izvršbo se slovenska izvršilna sodišča največkrat ukvarjajo takrat, kadar je v izvršilnem naslovu bilo odločeno o nedenarni obveznosti, ki jo mora dolžnik izpolniti. Poleg sklepov izdanih v sporih zaradi motenja posesti so takšni izvršilni naslovi še odločbe o stikih z otrokom in odločbe izdane v delovnopravnih sporih. ${ }^{23}$

Primernost izvršilnega naslova pa izvršilno sodišče presoja tudi v primeru vloženega predloga za izvršbo na podlagi izvršilnega naslova, iz katerega izhaja denarna obveznost dolžnika. Največkrat se vprašanja o primernosti izvršilnega naslova pojavljajo $\mathrm{v}$ zvezi $\mathrm{z}$ neposredno izvršljivimi notarskimi zapisi. Gre predvsem za pogodbe o potrošniških hipotekarnih kreditih, ki so sklenjene v obliki neposredno izvršljivih notarskih zapisov. $\mathrm{V}$ teh primerih je namreč bistveno, da hipotekarni upnik v predlogu za izvršbo svojo terjatev specificirano navede, kar pomeni, da znesek dolga navede strukturirano, po posameznih naslovih: glavnica, obresti (pogodbeno dogovorjene, zamudne) in t. i. bančni stroški. Le če upnik svojo terjatev navede po posameznih postavkah, in sicer na določen presečni dan (na dan odstopa od kreditne pogodbe), bo sodišče lahko preverilo skladnost izvršilnega predloga z izvršilnim naslovom ter preizkusilo primernost izvršilnega naslova za izvršbo. Iz sodne prakse izhaja, da sodišče ne sme dovoliti izvršbe za obveznosti, ki so v notarskem zapisu posplošeno navedene, največkrat gre za stroške oziroma nadomestila iz kreditnega razmerja, ki niso opredeljena po višini. ${ }^{24} \mathrm{~V}$ takem primeru mora izvršilno sodišče predlog za izvršbo (delno) zavrniti iz razloga neprimernosti izvršilnega naslova za izvršbo.

Najpogostejši domači izvršilni naslovi, v katerih je vsebovana premalo določna obveznost dolžnika, so torej tisti izvršilni naslovi, ki dolžniku nalagajo izpolnitev

20 Gesetz vom 27. Mai 1896, über das Exekutions- und Sicherungsverfahren (Exekutionsordnung -EO). StF: RGB1. Nr. 79/1896, nazadnje noveliran BGB1. I Nr. 100/2016.

${ }^{21} \S 7 / 1$ EO (nenoveliran): »Die Execution darf nur bewilligt werden, wenn aus dem Executionstitel nebst der Person des Berechtigten und Verpflichteten auch Gegenstand, Art, Umfang und Zeit der geschuldeten Leistung oder Unterlassung zu entnehmen sind."

22 BGB1. Nr. 624/1994.

23 Glej primere izrekov odločb v (Merc 2015a, str. 604-606).

24 VSM sklep I Ip 431/2015-1 z dne 17. 9. 2015. 
nedenarne obveznosti. V zvezi z izvršitvijo teh izvršilnih naslovov je pogosto treba postaviti sodnega izvedenca, ki je postavljen bodisi $\mathbf{z}$ namenom razjasnitve vsebine obveznosti, ki izhaja iz izvršilnega naslova (izrek je pomanjkljiv oziroma nejasen $)^{25}$ bodisi $\mathbf{z}$ namenom ugotovitve, ali je dolžnik obveznost izpolnil (npr. $\mathrm{v}$ primeru motenjskih sporov, da je dolžnik odstranil oviro in upniku omogočil, da neovirano izvaja soposest hoje in vožnje). ${ }^{26}$ Postavitev sodnega izvedenca iz navedenih razlogov vedno povzroči zastoj izvršilnega postopka. Prav tako se izvršilni postopek spreminja v pravdnega, kar je nedopustno. Kadar so npr. v sporih zaradi motenja posesti prepovedana motitvena dejanja nedoločno opredeljena, in v izvršilnem naslovu vrsta in obseg izpolnitve obveznosti nista ustrezno opredeljena, takrat je treba predlog za izvršbo zavrniti iz razloga neprimernosti izvršilnega naslova za izvršbo. ${ }^{27}$

Poseben problem v slovenskih izvršilnih postopkih predstavljajo sodbe, izdane $\mathbf{v}$ delovnih in socialnih sporih. Že pri oblikovanju tožbenih zahtevkov je nekoliko več težav, kakor v klasičnih civilnih pravdah. Sodišča v teh sporih ne bi smela dopuščati pavšalno (opisno) oblikovanih zahtevkov, ${ }^{28}$ tožbeni zahtevek bi moral biti jasno določen. Ker iz izrekov sodb delovnih in socialnih sodišč navadno izhaja bruto znesek, se postavlja vprašanje, ali je $v$ teh primerih denarna obveznost, ki jo mora dolžnik izpolniti, dovolj določljiva.

\section{Poglejmo primer:}

\section{sodbe delovnih sodišč navadno vsebujejo sledeči izrek:}

»Tožena stranka je dolžna tožeči stranki za mesec 2017 obračunati plačo v bruto znesku___EUR, plačati prispevke in davke iz bruto zneska ter tožeči stranki izplačati neto znesek z zakonskimi zamudnimi obrestmi od 2017 dalje.

Iz navedenega izreka izhaja, da je delavec upravičen do bruto plače, ki pa jo mora delodajalec izplačati tako, da za delavca obračuna akontacijo davka od osebnih prejemkov in prispevke za socialno varnost, obračunane zneske plačati na ustrezne račune ter delavcu izplačati preostanek (neto plačo). ${ }^{29}$ Če je v izreku sodbe vsebovan bruto znesek plače in mesec, na katerega se izplačilo nanaša (kot je nakazano v zgornjem primeru) oziroma bruto znesek regresa za letni dopust, je obveznost dolžnika določljiva ter posledično izvršilni naslov primeren za izvršbo. Tudi pravna teorija je zavzela stališče, da je denarni zahtevek za plačilo plače dovolj konkretiziran, če je plača opredeljena v bruto znesku, čeprav se delavcu dejansko izplača neto znesek. ${ }^{30} \mathrm{~V}$ Sloveniji je namreč uveljavljen sistem bruto dohodkov. Navedeno pomeni, da je delavec upravičen do plače v bruto znesku, le da celotnega

25 Npr. postavitev izvedenca zaradi izrisa služnostne poti, ker ni jasen obseg odstranitve ovir na služnostni poti.

26 Glej tudi VSM sklep I Ip 891/2017 z dne 29. 11. 2017.

27 VSL sklep III Ip 1628/2014 z dne 3. 9. 2014.

28 (Robnik 2010, str. 116-117).

29 Prim. (Pustovrh Pirnat 2009, str. 974).

30 Galič v (Ude et al. 2005-2010, 2. knjiga, str. 127). 
zneska ne prejme na svoj račun, temveč delodajalec takoj odtegne (zadrži) od bruto zneska del za plačilo javnih dajatev. ${ }^{31}$

Ker obveznost delodajalca, da za delavca odtegne akontacijo davka ter predpisane prispevke, zapade šele ob izplačilu plače, tudi v izreku sodbe ni mogoče navesti neto zneskov plače. ${ }^{32} \mathrm{~V}$ primeru izvršbe na podlagi sodbe delovnega sodišča se zato postavlja vprašanje, ali lahko upnik sam obračuna davke in prispevke že ob vložitvi predloga za izvršbo (ko mu datum izplačila plače še ni znan) in svojo terjatev izterjuje kot denarno terjatev ali gre pri izterjavi davkov in prispevkov za nenadomestno dejanje, ki ga lahko opravi le dolžnik (delodajalec) in mora upnik zato predlagati izvršbo zaradi izterjave nedenarne terjatve. Navedeno je pomembno, saj so predlagana sredstva izvršbe drugačna glede na denarno oziroma nedenarno terjatev. Dolžnost upnika je, da predlaga pravilno sredstvo izvršbe. Če tega ne stori, je treba predlog za izvršbo zavrniti.

Sodna praksa se glede vprašanja, ali lahko upnik z izračunom davkov in prispevkov spremeni nedenarno terjatev v denarno, še ni poenotila. Eno stališče je, da upnik plačila davkov in prispevkov, ki jih je dolžan obračunati in na ustrezne račune plačati delodajalec pri izplačilu plače, ne more izterjevati kot plačilo denarne terjatve, temveč lahko le neto plačo izterjuje kot denarno terjatev, plačilo davkov in prispevkov pa kot nedenarno terjatev ${ }^{33}$ Nedenarna obveznost se tako izvršuje po določilu 226. člena ZIZ, to je z naložitvijo denarne kazni, če dolžnik v določenem roku ne izpolni obveznosti.

Drugo (novejše) stališče sodne prakse pa je, da obračun davkov in prispevkov ni samostojna nenadomestna nedenarna obveznost, ki jo lahko opravi le dolžnik, temveč gre pri obračunu za dejanje, ki ga lahko opravi kdorkoli, ki ima na voljo obračunsko orodje, ki upošteva predpisane zakonske elemente. Iz tega razloga se obračun plače, regresa in pripadajočih javnih dajatev obravnava kot denarna terjatev, saj je obračun nedeljivo povezan z denarno obveznostjo (bruto zneskom) in pomeni nepogrešljivi del izpolnitvenega ravnanja plačila. Gre za celoto obveznosti, ki jo mora dolžnik izpolniti, to je plačilo plače, ki pa je v izvršilnem naslovu opredeljena le v bruto znesku. Tako za prvi (neto plača) kot drugi del obveznosti (obračun in plačilo javnih dajatev) se mora plača najprej obračunati in ni razloga, da se zanemari povezanost obračuna kot sestavnega dela izpolnitvenega ravnanja plačila. Upnik je torej tisti, ki mora denarno obveznost določno (zneskovno) opredeliti in razdelati $\mathrm{v}$ predlogu za izvršbo. Breme obračuna obveznosti je tako na upniku, ${ }^{34} \mathrm{ki}$ pa ni dolžan obračunov priložiti izvršilnemu predlogu. Sodišče tudi ni računovodski servis, ki bi preverjal pravilnost upnikovih obračunov. ${ }^{35}$ Dolžnik lahko pravilnosti obračuna, ki ga je opravil upnik, v ugovoru zoper sklep o izvršbi utemeljeno nasprotuje. ${ }^{36}$

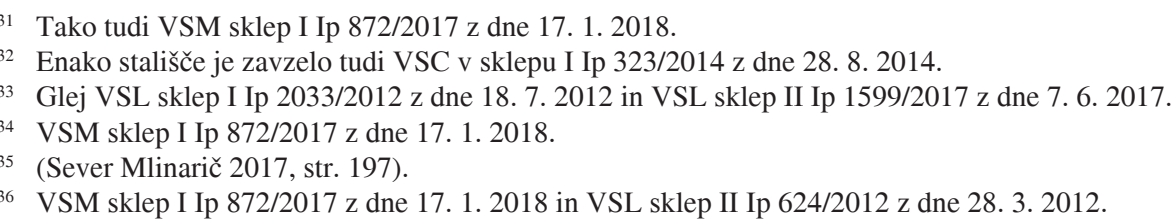


Zaradi nasprotujočih si stališč lahko vidimo, da ni povsem jasno, ali gre $\mathrm{v}$ primeru bruto zneskov za dolžnikovo denarno ali nedenarno obveznost. Res je sicer, da je izvršba praviloma hitreje končana, če upnik v celoti svojo terjatev izterjuje kot denarno terjatev, vendar se zaradi različnih davčnih stopenj, ki veljajo na dan nastanka obveznosti plačila davka, postavlja vprašanje, ali je res pravilno, da upnik obračuna davke in prispevke že v predlogu za izvršbo. Davki in prispevki se obračunajo po stopnjah, ki veljajo v času izplačila ${ }^{37}$ (ko delavec dejansko prejme neto znesek plače), davčna obremenitev pa je odvisna tudi od osebnih razmer zavezanca, ki se spreminjajo (olajšave). Višje delovno in socialno sodišče je zavzelo stališče, da bi bilo nepravilno, če bi sodba sodišča prve stopnje navajala konkretne zneske davkov in prispevkov, ki jih mora dolžnik (tožena stranka) obračunati in vplačati. ${ }^{38}$ Problem nastane v izvršbi predvsem zato, ker mora običajno upnik v predlogu za izvršbo navesti neto zneske, npr. plače, ki jih izterjuje kot denarno terjatev (če sam tega ne stori, ga sodišče k temu pozove), in mora že takrat opraviti obračun davkov in prispevkov, da lahko pride do neto zneskov (davek in prispevke obračuna po stopnjah, kot veljajo v času sestave predloga za izvršbo oziroma na datum, kot ga sam izbere, saj mu dan plačila obveznosti ni znan), kar pa ni pravilno. ${ }^{39}$ Preračun terjatve ob vložitvi predloga za izvršbo zato ne more biti nikoli pravilen. Pritrditi je sicer drugemu stališču, da je bruto obveznost dolžnika treba presojati kot celoto, vendar bi s stališča pravilnega obračuna terjatve bilo treba celotno obveznost izterjevati kot nedenarno terjatev, če bi hoteli, da je obračun plače do centa pravilen. Delavci bi v primeru izterjave plače kot nedenarne terjatve bili v takem primeru še na slabšem (denarna kaznovanja delodajalcev na podlagi 226. člena ZIZ v praksi niso uspešno sredstvo izvršbe). Iz tega razloga sem zato bolj naklonjena drugemu novejšemu stališču, ki ga je zavzela sodna praksa, saj se zdi najbolj ekonomično, in v okviru hitrega postopka izvršbe najbolj pravilno, obračun in plačilo plače, davkov in prispevkov obravnavati v celoti kot denarno terjatev.

V zvezi s problematiko izterjave plačila davkov in prispevkov za socialno varnost pa se zastavlja tudi vprašanje, ali je sploh podana sodna pristojnost, saj je v skladu z veljavno zakonodajo davčni organ tisti, ki je izključno pristojen za nadzor nad plačilom davkov in prispevkov ter njihovo izterjavo. Navedene obveznosti se lahko izterjajo tudi $v$ davčnem postopku. Na to vprašanje je že odgovorila ustaljena sodna praksa delovnih sodišč ${ }^{40}$ do tega vprašanja pa se je opredelilo tudi Višje sodišče v Mariboru, ki je v obrazložitvi sklepa I Ip 872/2017 z dne 17. 1. 2018 zapisalo: „Civilna izvršba je tako primarno pravno varstvo dolžnika, ki ga dopolnjuje javnopravno varstvo Finančne uprave RS. « Nasprotno pa se je do tega vprašanja opredelilo Vrhovno sodišče RS, ki je v sodbi VIII Ips 226/2017 z dne 23. 1. 2018 sprejelo stališče, da sodišče v delovnem sporu ne odloča tudi o tem, ali

37 O tem, kdaj nastane obveznost plačila davčnega odtegljaja, glej VSRS sklep II Ips 313/2015 z dne 20. 4. 2017.

38 Glej (Sever Mlinarič 2017, str. 190-191).

39 Več o dnevu preračuna bruto zneskov v neto zneske glej (Sever Mlinarič 2017, str. 199).

40 Več o sodni pristojnosti glede obračunavanja in plačila davkov in prispevkov glej (Sever Mlinarič 2017, str. 188-189 in 193). 
je delodajalec, ob prisojenem prejemku delavcu iz delovnega razmerja ali v zvezi z njim, dolžan obračunati in plačati davke in prispevke oziroma od katerih osnov jih je dolžan obračunati in plačati, saj gre v tem delu za javnopravno razmerje. $\mathrm{Ob}$ izplačilu prejemka je to stvar izplačevalca (delodajalca) oziroma pristojnih davčnih organov. ${ }^{41}$ Zaradi novejšega razvoja sodne prakse so začela tudi delovna sodišča tožbene zahtevke v delu, ki se nanašajo na odvod (tj. plačilo) davkov in prispevkov od pripadajočih bruto zneskov plač, zavračati, saj gre za pristojnost davčnih organov. Posledično se novejše sodbe delovnih sodišč, ki ne vsebujejo zahtevka "plačati prispevke in davke iz bruto zneska«, v tem delu tudi več ne izterjujejo v izvršilnem postopku. Zaključimo lahko, da je sodna praksa slovenskih sodišč glede izvrševanja sodb delovnih sodišč zelo neenotna in da na izpostavljena vprašanja še ni enotnih odgovorov. Bistveno vlogo bodo v prihodnosti imela delovna sodišča, ko bodo odločala o postavljenih zahtevkih tožnikov, saj so izvršilna sodišča le tista, ki sodbe delovnih sodišč v skladu z načelom formalne legalitete izvršujejo.

\section{RAZLIKOVANJE DENARNE IN NEDENARNE OBVEZNOSTI}

\subsection{Splošno}

Osnovna razmejitev obveznosti, ki jih upniki izterjujejo v izvršilnem postopku, je delitev na denarne in nedenarne obveznosti. Denarna obveznost je obveznost, za katero je značilno, da je njen predmet plačilo določenega denarnega zneska (denarna dajatvena obveznost), nedenarna obveznost pa je vsaka obveznost, ki ni denarna obveznost: nedenarna dajatvena obveznost, storitvena obveznost, opustitvena obveznost in dopustitvena obveznost. ${ }^{42}$ ZIZ sicer govori o izvršbi za izterjavo denarne terjatve ${ }^{43}$ in izvršbi za uveljavitev nedenarne terjatve. ${ }^{44}$ Tudi v 16. členu ZIZ, v katerem so pojasnjeni pomeni posameznih izrazov, ne najdemo izraza »obveznost«, temveč ZIZ govori o »terjatvi«. Ker gre za pravno razmerje med upnikom in dolžnikom, je tudi logično, da gre na eni strani za terjatev, na drugi strani pa za obveznost. Ne glede na uporabo izraza pa je pomembno, ali upnik izterjuje »denarno« ali »nedenarno « obveznost. ZIZ nedenarne obveznosti razčlenjuje še na: izročitev in dobavo premičnin; izpraznitev in izročitev nepremičnin; na obveznost, kaj storiti, dopustiti ali opustiti; na vrnitev delavca na delo; na razdelitev stvari in na izjavo volje. ${ }^{45}$ Pomembnost razmejitve se kaže tudi v zakonu dano pooblastilo za odločanje o predlogu za izvršbo. V skladu s 6. členom ZIZ lahko o dovolitvi izvršbe zaradi izterjave denarne terjatve odločajo tudi strokovni sodelavci in sodniški pomočniki, medtem ko je za dovolitev izvršbe zaradi izterjave nedenarne 19).

${ }^{41}$ Več o pomenu tega stališča VSRS glej (Robnik 2018, str. 6-7) in (Kogej Dmitrovič 2019, str.18-

42 Plavšak v (Plavšak, Juhart, and Vrenčur 2009, str. 103).

43 Osmo poglavje ZIZ.

44 Petnajsto poglavje ZIZ.

45 (Rijavec 2003, str. 113). 
terjatve pristojen le sodnik posameznik. Če bi o predlogu za izvršbo zaradi izterjave nedenarne terjatve odločil strokovni sodelavec, bi bil takšen sklep obremenjen z absolutno bistveno kršitvijo določb postopka iz 1. točke drugega odstavka 339. člena Zakona o pravdnem postopku v zvezi s 15 . členom ZIZ. ${ }^{46}$

\subsection{Valorizacija denarnih obveznosti}

Največkrat izvršba teče zaradi izterjave denarne obveznosti. Ker so načeloma te obveznosti natančno določene, tj. $\mathrm{z}$ absolutnim denarnim zneskom, ki ga je treba plačati, težav pri njihovi izvršitvi ni zaslediti. V zvezi z denarnimi obveznostmi se težave pojavijo takrat, kadar je $\mathbf{v}$ izvršilnem naslovu vsebovana valorizacija denarne obveznosti (indeksna ali valutna klavzula). Gre torej za primere, ko denarna obveznost ni določena, temveč določljiva. Višina denarne obveznosti se določi glede na spremembe cen za blago in storitve, izraženih z indeksom cen, ki ga ugotavlja pooblaščena organizacija. ${ }^{47}$ Takšen tipični primer izvršilnega naslova, ki vsebuje indeksno klavzulo, je sodna odločba (oziroma sodna poravnava) izdana v postopkih določitve preživnin, in sicer se glasi:

»... Dospevajoče preživninske obroke se toženec zaveže plačevati do 15. dne $v$ mesecu za tekoči mesec in to $v$ zneskih, ki so določeni s to poravnavo do prve uskladitve preživnin $z$ indeksom rasti cen življenjskih potrebščin v Republiki Sloveniji. Pisno obvestilo Centra za socialno delo o vsakokratni uskladitvi in novem znesku preživnine je skupaj s to poravnavo izvršilni naslov ... «48

Obveznost dolžnika tako v času izdaje sodne odločbe ni znana in je odvisna od indeksa rasti cen življenjskih potrebščin v Republiki Sloveniji. Pisno obvestilo Centra za socialno delo o vsakokratni uskladitvi in novem znesku preživnine že vsebuje valoriziran mesečni znesek preživnine, zato težav pri dovolitvi izvršbe ni. ${ }^{49}$ Do problemov prihaja zlasti takrat, kadar izvršilni naslov vsebuje le klavzulo »z indeksom rasti cen življenjskih potrebščin«, pri čemer ni navedena organizacija, ki ugotavlja povišanje, niti ni navedeno za indeks rasti cen življenjskih potrebščin, za katero državo gre. ${ }^{50} \mathrm{~V}$ takem primeru se postavi vprašanje, ali je izvršilni naslov sploh primeren za izvršbo.

Izvršilni naslov lahko vsebuje tudi valutno klavzulo, ki pomeni, da je višina dolžnikove denarne obveznosti določena glede na gibanje tečaja tuje valute. ${ }^{51} \mathrm{~V}$ Republiki Sloveniji je evro domača valuta, denarne enote vseh drugih držav izven evroobmočja pa so tuje valute. $\mathrm{O}$ valutni klavzuli govorimo, kadar je tuja valuta

46 Glede nepravilne sestave sodišča glej tudi VSM sklep I Ip 133/2019 z dne 8. 5. 2019.

47 372. člen Obligacijskega zakonika (v nadaljevanju OZ, Uradni list RS, št. 83/01, 32/04, 28/06-odl. US, 40/07, 64/16 - odl. US, 20/18 - OROZ631).

48 Primer je naveden tudi (Merc 2015a, str. 601).

49 Upnik predlogu za izvršbo priloži izvršilni naslov in vsa obvestila Centra za socialno delo, iz katerih izhaja vsakokratni valoriziran znesek preživnine za naslednje obdobje.

50 Glej primer tujega izvršilnega naslova, ki vsebuje indeksno klavzulo v (Merc 2015a, str. 602).

51 372. člen OZ. 
uporabljena kot merilo vrednosti za določitev predmeta obveznosti, katere izpolnitev je treba opraviti v domači valuti. ${ }^{52}$ Kot primer lahko navedemo sodbe hrvaških sodišč, ki jih upniki pogosto kot izvršilni naslov predložijo v slovenskem izvršilnem postopku. Iz sodbe hrvaškega sodišča na primer izhaja, da mora dolžnik plačati upniku »znesek 500,00 EUR v protivrednosti v kunah po prodajnem tečaju $X$ banke d.d., v kraju izpolnitve na dan plačila ${ }^{53}{ }^{53} \mathrm{Ob}$ izdaji sodbe torej ni znano število denarnih enot v domači valuti (v konkretnem primeru v kunah), ${ }^{54}$ saj je z valutno klavzulo določena vrednost določene količine denarnih enot, izraženih v tuji valuti (v konkretnem primeru v evrih) na dan izpolnitve. Gre za nepristno valutno terjatev, ki pomeni, da je tuja valuta uporabljena le kot merilo vrednosti, plačilo obveznosti pa mora biti opravljeno v domači valuti. ${ }^{55}$ Če je taka sodba (oziroma tuj izvršilni naslov) predložena v izvršitev v Republiki Sloveniji, se zastavlja vprašanje, kako je treba dovoliti izvršbo, torej ali se izvršba dovoli v evrih brez preračunavanja v HRK na dan plačila, ali tako da se ob opravljeni izvršbi evri preračunajo v HRK in nakažejo upniku. ${ }^{56}$

Če je v izvršilnem naslovu vsebovana tuja valuta (brez pristavka»v protivrednosti v evrih/kunah«) in upnik na njegovi podlagi predlaga izvršbo v Republiki Sloveniji, se prav tako zastavlja vprašanje, ali je pravilno dovoliti in opraviti izvršbo v tuji valuti (brez preračunavanja), ali je že ob dovolitvi izvršbe treba opraviti preračun v domačo valuto (evre), ali pa morda preračun treba opraviti šele ob poplačilu. Ker gre v tem primeru za pristno valutno terjatev, tj. terjatev, ki je izražena v tuji valuti in katere izpolnitev je treba opraviti s tujimi plačilnimi sredstvi, ${ }^{57}$ bi bilo pravilno zaključiti, da je izvršbo treba dovoliti v tuji valuti ter da se ob poplačilu upniku nakaže tudi tuja valuta brez preračunavanja $v$ evre. Tuja valuta v primeru pristnih valutnih terjatev poleg merila vrednosti opravlja tudi funkcijo plačilnega sredstva. ${ }^{58}$

Na podlagi navedenega lahko vidimo, da obstajajo v primeru denarnih obveznosti različne situacije oziroma različni izreki izvršilnih naslovov, pri čemer gre v teh primerih navadno za določljivo obveznost, saj je s pomočjo indeksne oziroma valutne klavzule višino dolžnikove obveznosti mogoče določiti. Enako velja za obresti, ki izhajajo iz izvršilnega naslova.

52 (Plavšak 2003, str. 514).

33 Glej tudi primer v (Merc 2015a, str. 602-603).

54 Če se sodba izvršuje na Hrvaškem.

5 (Plavšak 2003, str. 514).

5 Več o tem v podpoglavju 6.2.2. Terjatev v tuji valuti.

(Plavšak 2003, str. 514).

58 Prav tam, 514. 


\section{DOLOČNA, DOLOČLJIVA OZIROMA POMENSKO DOLOČLJIVA OBVEZNOST V IZVRŠILNEM NASLOVU}

Predmet denarne obveznosti je tako lahko bodisi določen bodisi določljiv. ${ }^{59}$ V obligacijskem pravu velja dispozitivno pravno pravilo 371. člena OZ (načelo monetarnega nominalizma), ki pomeni, da mora dolžnik plačati upniku tisto število denarnih enot, na katero se glasi obveznost, če se upnik in dolžnik v skladu z zakonom nista dogovorila drugače (npr. za valorizacijo). Če torej iz izvršilnega naslova izhaja absolutni denarni znesek, je predmet obveznosti določen. Predmet obveznosti je določljiv, kadar izvršilni naslov vsebuje podatke, na podlagi katerih je mogoče višino denarne obveznosti določiti, npr. valorizacijsko klavzulo, ${ }^{60}$ kadar se sklicuje na zakon, ki določa višino obrestne mere, in kadar je obveznost opredeljena v bruto znesku (neto znesek pa je mogoče izračunati ob danih podatkih). Ob plačilu obveznosti oziroma ob realizaciji izvršbe je tako mogoče izračunati natančno višino dolžnikove obveznosti (t. i. čisto denarno terjatev). Valorizacija denarnih obveznosti je nasprotje monetarnega nominalizma, stranki pa se za valorizacijo dogovorita, saj lahko na ta način dosežeta, da ima vsota denarnih enot, ki so predmet obveznosti, ob dejanskem plačilu enako kupno moč kot v času nastanka obveznosti. ${ }^{61}$ Nadalje zakonske zamudne obresti v sodbah slovenskih sodišč niso nikoli opredeljene tako, da bi bil naveden odstotek obrestne mere, saj je le-ta določen z zakonom in se spreminja. Ker je vedno mogoče določiti oziroma izračunati zamudne obresti, je tudi tak predmet obveznosti določljiv. ${ }^{62}$ Denarna obveznost pa ni samo določljiva takrat, kadar gre za zakonske zamudne obresti, temveč tudi v primeru rednih pogodbenih obresti (in tudi pogodbenih zamudnih obresti), ki so navadno vsebovane $\mathrm{v}$ neposredno izvršljivih notarskih zapisih (npr. kreditnih pogodbah, sklenjenih v obliki notarskega zapisa). Če je odstotek obrestne mere določen in je navedena tudi višina glavnice, ter način in obdobje obrestovanja, je obveznost dolžnika določljiva (denarno dajatveno obveznost je mogoče izračunati). Določljivost obveznosti izhaja iz 38. člena OZ, ki pravi: »Predmet obveznosti je določljiv, če vsebuje pogodba podatke, s katerimi ga je mogoče določiti, ali če sta stranki prepustili nekomu tretjemu, naj ga določi. «O določljivosti obveznosti pri notarskih zapisih pa govorimo tudi takrat, kadar je obveznost v notarskem zapisu določena s podatkom, ki ima značilnost splošno znanega dejstva. Najpogosteje gre za podatek, ki ga javno objavlja določen pravni subjekt (na primer trimesečni ali šestmesečni EURIBOR). Obveznost v notarskem zapisu pa je določljiva tudi, kadar je $\mathrm{v}$ notarskem zapisu vsebovan podatek, ki ima značilnost drugega pravnega dejstva, ki ni splošno znano dejstvo. V takem primeru se mora to pravno dejstvo (podatek), od katerega je odvisna določitev obveznosti, izkazati z javno listino (npr. pri pogodbi o izdaji bančne garancije). Podobna je situacija, kadar iz izvršilnega

59 Drugi odstavek 34. člena OZ.

60 (Plavšak 2003, str. 517).

61 (Plavšak 2003, str. 520).

62 Glede določljivosti obrestne obveznosti v izvršilnem naslovu glej tudi VSRS sklep II Ips 557/2009 z dne 20. 5. 2010 in VSL sklep IV Cp 929/2005 z dne 8. 6. 2005. 
naslova izhaja pogojna (oziroma vzajemna) obveznost. Tudi v takem primeru mora upnik z ustrezno javno ali po zakonu overjeno listino izkazati nastop odložnega pogoja (oziroma izpolnitev vzajemne obveznosti), da lahko sodišče dovoli izvršbo (26. člen ZIZ). ${ }^{63}$

Bistvena prvina določljivosti je, da izvršilni naslov vsebuje vse potrebne elemente, na podlagi katerih je mogoče določiti višino dolžnikove obveznosti. ${ }^{64} \mathrm{~V}$ praksi to pomeni, da je denarna obveznost določljiva, kadar je izračunljiva. ${ }^{65}$ Pri obveznostih v bruto zneskih (pri sodbah delovnih sodišč) pa je kot že rečeno, prav tako bilo sprejeto stališče, da je obveznost $v$ teh primerih določljiva. Višje sodišče v Ljubljani je v sklepu II Ip 983/2018 z dne 16. 5. 2018 v zvezi z izvršitvijo sodb delovnih sodišč obrazložilo: »Obveznost kaj dati, storiti in opustiti, ki se nalaga $v$ izpolnitev dolžniku, mora tako biti v izvršilnem naslovu določena ali vsaj določljiva. Predmet obveznosti je določljiv, kadar je pravica vsaj opisno opredeljena in je določen čas trajanja ter s tem možnost njenega izračuna. Izvršilno sodišče namreč le poskrbi za izvršitev obveznosti, ki izhaja iz izvršilnega naslova in ki jo v predlogu za izvršbo zahteva upnik. " $\mathrm{Z}$ navedenim se je mogoče strinjati, ne pa pritrditi stališču, zavzetem v isti odločbi, da je obveznost, ki je vsebovana v izreku sodne odločbe »lahko v polnem obsegu dokončno pomensko določljiva šele v povezavi zodločbo kot celoto « ${ }^{66}$ Vsebina obveznosti, ki je bila dolžniku naložena v izreku sodne odločbe, mora biti namreč toliko jasna oziroma določljiva, da izvršilnemu sodišču ni potrebno pogledati v obrazložitev sodne odločbe, zato da bi lahko dokončno določilo oziroma ugotovilo, kaj je vsebina dolžnikove obveznosti. Izvršilni postopek mora biti hiter in ni mogoče pričakovati od izvršilnega sodišča, da bo bralo obrazložitev sodbe, npr. delovnega sodišča, da bo ugotovilo natančno vsebino dolžnikove obveznosti. Le-ta mora biti jasna iz izreka sodne odločbe že na prvi pogled. Obrazložitev tako ne more nadomestiti pomanjkljivosti, ki izhajajo iz izreka sodne odločbe.

Obveznost v izvršilnem naslovu mora tako biti primerno opredeljena. To pomeni, da ne sme puščati nobenih dvomov o tem, kakšna obveznost je dolgovana, in od izvršilnega sodišča ne sme zahtevati dodatnega vsebinskega odločanja. ${ }^{67}$ Če obveznost ne izhaja direktno iz izreka sodne odločbe, je dopustno, da se izrek sklicuje na priložen seznam ali npr. skico poti. Kot primer lahko navedemo pravnomočen sklep o končanju postopka osebnega stečaja, ki mu je priložen seznam neplačanih priznanih terjatev, pri čemer je seznam sestavni del izreka sklepa.

Pri nedenarnih obveznostih prav tako velja, da mora biti predmet obveznosti določen oziroma določljiv. Obveznost, vsebovana vizvršilnem naslovu (individualno določena stvar; vrsta in količina nadomestnih stvari, ki jih je zavezanec dolžan dati; storitev; opustitev ali dopustitev), mora biti natančno navedena oziroma mora biti takšna, da jo je mogoče izvršiti. Če obveznosti ni mogoče izvršiti, takšen izvršilni

63 Več o določno opredeljeni obveznosti v notarskih zapisih glej (Plavšak 2012, str. 1646).

64 Tako tudi VSL sklep III Cp 1002/2016 z dne 11. 5. 2016.

65 Glej VSL sklep III Cp 1467/2004 z dne 30. 3. 2005 in 7.točko obrazložitve sklepa VSL II Ip 4053/2013 z dne 10. 1. 2014.

66 VSL sklep II Ip 983/2018 z dne 16. 5. 2018.

${ }_{67}$ VSL sklep I Ip 748/2015 z dne 22. 4. 2015 in VSL sklep II Ip 2533/2015 z dne 16. 10. 2015. 
naslov ni primeren za izvršbo. Skladno z drugim odstavkom 34. člena OZ mora biti predmet obveznosti torej tudi mogoč in dopusten. Predmet je nedopusten, če je v nasprotju z ustavo, prisilnimi predpisi ali z moralnimi načeli (37. člen OZ). V primeru nedopustnosti predmeta obveznosti izvršilno sodišče ne sme dovoliti izvršbe. ${ }^{68}$

\section{POJEM ZADOSTNO OPREDELJENE TERJATVE IN MEJNI PRIMERI}

Temeljno vprašanje, ki se pri presoji primernosti izvršilnega naslova za izvršbo odpira je, kdaj je terjatev opredeljena tako, da bo v smislu določenosti zadostovala za dovolitev izvršbe. Glavno merilo, ki ga je treba upoštevati je, da mora biti terjatev opredeljena tako, da od izvršilnega sodišča ne zahteva nadaljnjega vsebinskega odločanja.

Pri nedenarnih obveznostih velja enako kot pri denarnih, da mora obveznost jasno izhajati že iz izreka sodne odločbe. Določljivost obveznosti namreč pomeni, da izhajajo vsi podatki, na podlagi katerih je mogoče obveznost določiti, že iz samega izreka sodne odločbe. Zato ni mogoče trditi, da je obveznost zadostno opredeljena, kadar iz izreka sodne odločbe izhaja dolžnikova obveznost »izročitve premičnin tehničnega lesa - kostanja cca. $60 \mathrm{m3}$, ki se nahaja na travniku ${ }^{69} \mathrm{~V}$ izreku bi moralo biti opredeljeno, za kateri travnik gre, ali pa bi se izrek sodne odločbe moral sklicevati na priloženo skico, ki bi kazala natančen kraj, kjer se les nahaja. Gre namreč za točno določen les na točno določeni lokaciji. Ni mogoče pričakovati, da bo izvršitelj (ob opravi izvršbe) iz vsebine obrazložitve sodne odločbe ugotavljal, na katerem travniku se les sploh nahaja. Načelo formalne legalitete namreč preprečuje izvršilnemu sodišču, da bi samo dopolnjevalo izvršilni naslov na način, da bi z nadaljnjim pravnim sklepanjem »razbralo« obveznost, ki neposredno v izreku sodbe kot izvršilnem naslovu ni zapisana. ${ }^{70}$ Enakega stališča je tudi Galič, ki še dodatno opozarja, da morajo biti tožbeni zahtevki podani v pravdnem postopku konkretizirani, zato da se ne bi pravo vsebinsko odločanje iz pravdnega postopka preneslo $\mathrm{v}$ izvršilni postopek. ${ }^{71}$

Nemalokrat se v sporih zaradi motenja posesti zgodi, da izvršilno sodišče presoja zadostno opredeljenost terjatve (določenost oziroma določljivost nedenarne obveznosti). Problem se pojavi takrat, ko je v izvršilnem naslovu dolžniku naloženo, da vzpostavi prejšnje stanje. Iz samega izreka izvršilnega naslova, pa ne izhajajo vsi potrebni podatki, da bi dolžnik lahko svojo obveznost izpolnil. Če je npr. v pravnomočnem in izvršljivem sklepu, izdanem v motenjski pravdi, določeno, da dolžnik »vzpostavi prejšnje stanje tako, da nazaj postavi novo ograjo iz plastične

68 (Rijavec 2003, str. 113).

69 Nasprotno stališče je zastopalo VSM v sklepu I Ip 1182/2015 z dne 2. 2. 2016.

70 VSM sklep I Ip 201/2019 z dne 3. 4. 2019.

71 Galič v (Ude et al. 2005-2010, 2. knjiga, str. 123-124). Glej tudi VSL obrazložitev sodbe in sklepa II Cp 2940/2014 z dne 6. 5. 2015. 
zelene mreže višine 2 metrov na isto mesto, kot je bila postavljena pred motilnim dejanjem, in sicer: v predelu ob zahodni strani objekta ..., tik ob zahodni meji s parcelo $112 / 30$ k.o. ... v dolžini 15 metrov in še 3,5 metra, ki se nadaljuje v smeri proti severu, tik ob meji s parcelo $112 / 30 \mathrm{k} .0 . . . \ll{ }^{72}$ je treba presoditi, ali je sklep z navedeno vsebino izvršljiv oziroma primeren za izvršbo. V obravnavanem konkretnem primeru je Višje sodišče v Celju svojo odločitev, s katero je zavrnilo pritožbo dolžnika, obrazložilo z utemeljitvijo, da je izvršilni naslov primeren za izvršbo, saj je možno postavitev ograje jasno identificirati glede na jasne točke $\mathrm{v}$ naravi (objekt in meja) ter strani neba in jasno dolžino, pri čemer je bila meja določena v pravnomočni odločbi v nepravdni zadevi N 4/2013. ${ }^{73}$ Strinjamo se lahko, da je pri presoji primernosti izvršilnega naslova potrebno presojati vsebino celotnega izreka sodne odločbe (ugotovitveni, restitucijski in prepovedni del), vendar kljub temu ni mogoče pritrditi končnemu stališču sodišča, da je izvršilni naslov v konkretni zadevi primeren za izvršbo, saj se je prvostopenjsko sodišče spuščalo v vsebinsko presojo glede jasnega poteka meje. Ugotovilo je namreč, da je bila v nepravdnem postopku določena meja, tista meja, o kateri je govora v izvršilnem naslovu. Presoja primernosti izvršilnega naslova za izvršbo od izvršilnega sodišča ne sme terjati dodatnega vsebinskega odločanja ${ }^{74}$ kar pa v konkretni zadevi ni bilo upoštevano. Izvršilni naslov (v konkretni zadevi motenjski sklep) tudi ne napotuje oziroma se ne sklicuje na določitev meje v drugem postopku. Obseg izpolnitve nedenarne obveznosti je tako v motenjskem sklepu nejasno določen ter zaradi nezadostno opredeljene terjatve tudi neprimeren za izvršbo.

Zaključimo lahko, da je izvršilni naslov primeren za izvršbo, kadar je obveznost, ki jo mora dolžnik izpolniti določena oziroma določljiva, pri čemer so vsi potrebni elementi oziroma podatki navedeni v izreku sodne odločbe (ali tako, da se izrek sklicuje na priložen seznam ali skico) oziroma izhajajo iz sodne poravnave oziroma iz izvršljivega notarskega zapisa. Ni mogoče zahtevati niti od izvršilnega sodišča niti od drugih udeležencev izvršilnega postopka, da bodo prebirali obrazložitev sodne odločbe (ki je lahko več strani dolga) in pomensko določali obveznost, ki jo je treba izpolniti.

\section{PRIMERNOST TUJEGA IZVRŠILNEGA NASLOVA}

\subsection{Teoretična izhodišča}

Načelo formalne legalitete zavezuje izvršilno sodišče tudi pri dovolitvi izvršbe na podlagi tujega izvršilnega naslova. Ko sodišče prejme predlog za izvršbo, v katerem upnik predlaga izvršitev izvršilnega naslova, ki izhaja iz tujine, mora najprej preveriti formalne pogoje za dovolitev izvršbe. Formalni pogoji za dovolitev izvršbe

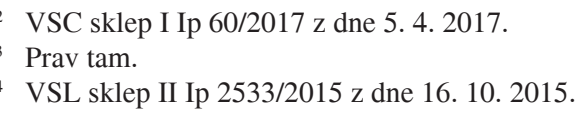


na podlagi tujega izvršilnega naslova so vsebovani v 40. členu ZIZ in 13. členu ZIZ. V 40. členu ZIZ, ki določa splošne sestavine predloga za izvršbo, je navedeno tudi, da morajo biti tujemu izvršilnemu naslovu priložene listine, iz katerih izhaja, da so izpolnjeni pogoji iz 13. člena ZIZ. Po prejšnji ureditvi, to je pred novelo ZIZ-L (pred 25. 3. 2019), ni bilo treba priložiti tuje sodne odločbe, temveč je bilo potrebno navesti le, da so izpolnjeni pogoji iz 13. člena ZIZ. Po sedanji ureditvi je torej treba priložiti tujo sodno odločbo, potrdilo o izvršljivosti in tudi drugo listino, ki izkazuje pogoje, da se lahko izvrši v Republiki Sloveniji (peti odstavek 40. člena ZIZ). Predvsem od izvora tujega izvršilnega naslova je odvisno, katere listine bo moral upnik priložiti k predlogu za izvršbo. Izvršilni naslov lahko namreč izvira iz države, ki ni članica Evropske unije (EU), ali iz države članice EU.

\subsubsection{Izvršilni naslov izvira iz države, ki ni članica $E U$}

Če izvršilni naslov izvira iz države, ki ni članica EU, se sme dovoliti in opraviti izvršba v Republiki Sloveniji, če tuja odločba, poravnava ali javna listina izpolnjuje z zakonom ali ratificirano in objavljeno mednarodno pogodbo predpisane pogoje za priznanje (1. alineja prvega odstavka 13. člena ZIZ). O priznanju in izvršitvi tujih sodnih odločb odloča v posebnem delibacijskem postopku okrožno sodišče, za izvršitev tuje odločbe pa je pristojno okrajno sodišče na območju, katerega je treba opraviti izvršbo (108. člen Zakona o mednarodnem zasebnem pravu in postopku) ${ }^{75}$ Lahko pa o priznanju tuje sodne odločbe, ki izvira iz države, ki ni članica EU, odloči tudi izvršilno sodišče (tj. okrajno sodišče) kot o predhodnem vprašanju, in sicer v okviru odločanja o dovolitvi izvršbe. Govorimo o t. i. »incidenter priznanju«, ki je možno le v primeru izvršitve izvršilnih naslovov iz držav, ki niso članice EU. ${ }^{76}$ Odločitev izvršilnega sodišča, ki je zajeta s sklepom o izvršbi, ima učinek le za konkreten postopek (šesti odstavek 108. člena ZMZPP). V praksi se izvršilno sodišče navadno ne ukvarja $\mathrm{z}$ vsebinskimi vprašanji glede priznanja veljavnosti tujih sodnih odločb, temveč upnika pozove na predložitev sklepa o priznanju tuje sodne odločbe (poziv skladno s 108. členom ZPP v zvezi s 15. členom ZIZ). Če izvršilni naslov izvira iz države, ki ni članica EU, se glede priznanja in izvršitve uporabi mednarodna pogodba med državama, ${ }^{77}$ če le te ni, se uporabi nacionalno pravo, in sicer ZMZPP glede sodnih odločb, sodnih poravnav oziroma odločb drugih organov, glede notarskih listin pa tudi ZN.

ZMZPP v 94. členu določa, da je tuja sodna odločba izenačena z odločbo sodišča RS le, če jo prizna sodišče RS. Dokler sodišče bodisi v samostojnem postopku bodisi kot o predhodnem vprašanju ne odloči o priznanju tuje sodne odločbe, ta v Sloveniji po ZMZPP ne učinkuje. ${ }^{78}$ Primer sklepa o priznanju veljavnosti tuje sodbe se glasi:

\footnotetext{
75 V nadaljevanju ZMZPP, Uradni list RS, št. 56/99, 45/08 - ZArbit.

76 Tako tudi (Rijavec 2003, str. 62) in VSL sklep II Ip 645/2019 z dne 9. 5. 2019.

77 Glej 4. člen ZMZPP.

78 (Galič 2006, str. 82).
} 
»Na območju Republike Slovenije se prizna veljavnost sodbe Občinskega civilnega sodišča $v$........., opr. št. ..... z dne ...., ki je postala pravnomočna in izvršljiva dne ...."

Izvršba na podlagi tuje sodne odločbe, ki izvira iz države nečlanice EU, tako zajema tri stadije:

1. (pravdni) postopek pred tujim sodiščem, ki se konča s pravnomočno in izvršljivo odločbo,

2. priznanje te tuje sodne odločbe v Republiki Sloveniji in

3. izvršba priznane tuje sodne odločbe po določilih ZIZ. ${ }^{79}$

V kolikor upnik v postopku priznanja veljavnosti tuje sodne odločbe predlaga tudi razglasitev izvršljivosti tuje sodne odločbe, mora v skladu z drugim odstavkom 103. člen ZMZPP priložiti tudi potrdilo o izvršljivosti sodne odločbe po pravu države, $v$ kateri je bila izdana. $V$ takem primeru se izrek sklepa o priznanju in izvršljivosti tuje sodne odločbe glasi:

»Na območju Republike Slovenije se prizna veljavnost in razglasi izvršljivost sodbe Okrajnega sodišča v ..., opr. št. ... z dne ...«

Upnik mora torej predlogu za izvršbo priložiti tujo sodno odločbo ter sklep okrožnega sodišča, iz katerega izhaja priznanje veljavnosti in izvršljivosti le-te.

\subsubsection{Izvršilni naslov izvira iz države, ki je članica $E U$}

Če izvršilni naslov izvira iz države, ki je članica EU, se glede priznanja in izvršitve tujega izvršilnega naslova uporabijo uredbe EU. Novela ZIZ-L je dopolnila oziroma spremenila obstoječe določbe in sedaj ZIZ ločuje dva postopka. Prvi postopek je takšen, kjer je v skladu z uredbami EU (Uredba 44/2001/ES, ${ }^{80}$ Uredba 2201/2003/ $\mathrm{ES},{ }^{81}$ Uredba 4/2009/ES, ${ }^{82}$ Uredba 2016/1103/EU ${ }^{83}$ in Uredba 2016/1104/EU) ${ }^{84} \mathrm{v}$ določenih primerih (ne pa $\mathrm{v}$ vseh) še vedno treba izvesti postopek priznanja in izvršitve tuje odločbe, tuje poravnave oziroma tuje javne listine pred pristojnim okrožnim sodiščem (42b. člen ZIZ). V tem primeru se glede postopka smiselno uporabijo določbe ZMZPP, če v posamezni uredbi ali v 42.b členu ZIZ ni drugače

79 Več o priznavanju (in izvršitvi) sodnih odločb iz neevropskih držav glej (Sladič 2013a, str. III priloge)

${ }^{80}$ Uredba Sveta (ES) št. 44/2001 z dne 22. decembra 2000 o pristojnosti in priznavanju ter izvrševanju sodnih odločb v civilnih in gospodarskih zadevah (v nadaljevanju Bruseljska uredba I oziroma BU I).

81 Uredba Sveta (ES) št. 2201/2003 z dne 27. novembra 2003 o pristojnosti in priznavanju ter izvrševanju sodnih odločb $\mathrm{v}$ zakonskih sporih in sporih $\mathrm{v}$ zvezi s starševsko odgovornostjo ter o razveljavitvi Uredba (ES) št. 1347/2000.

82 Uredba Sveta (ES) št. 4/2009 z dne 18. decembra 2008 o pristojnosti, pravu, ki se uporablja, priznavanju in izvrševanju sodnih odločb ter sodelovanju v preživninskih zadevah.

83 Uredba Sveta (EU) št. 2016/1103 z dne 24. junija 2016 o izvajanju okrepljenega sodelovanja na področju pristojnosti, prava, ki se uporablja, ter priznavanja in izvrševanja odločb na področju premoženjskih razmerij med zakoncema.

84 Uredba Sveta (EU) št. 2016/1104 z dne 24. junija 2016 o izvajanju okrepljenega sodelovanja na področju pristojnosti, prava, ki se uporablja, ter priznavanja in izvrševanja odločb na področju premoženjskopravnih posledic registriranih partnerskih skupnosti. 
določeno (četrti odstavek 42b. člena ZIZ). Drugi postopek (po Uredbi 1215/2012/ $\mathrm{EU}^{85}$ in Uredbi 606/2013/EU $)^{86}$ pa je takšen, da ni treba izvesti postopka priznanja in izvršitve, in je urejen v a42b. členu ZIZ. Postopek razglasitve izvršljivosti namreč po teh dveh uredbah ni predviden, zato so tuje odločbe, tuje poravnave oziroma tuje javne listine neposredno izvršljive. Predlogu za izvršbo pa je treba priložiti potrdilo o izvršljivosti skladno z določbo 42a. člena ZIZ, ki ga na zahtevo stranke izda sodišče ali organ, ki je odločal na prvi stopnji ali notar, ki je sestavil javno listino.

Kadar torej upnik razpolaga s tujim izvršilnim naslovom, ki izvira iz države članice EU, mora sam najprej ugotoviti, na podlagi katere uredbe EU bo lahko predlagal izvršbo oziroma uporaba katere uredbe bo prišla v poštev. $42 \mathrm{~b}$. člen ZIZ in a42b. člen ZIZ predstavljata implementacijo zgoraj navedenih uredb. Gre za specialni (postopkovni) določbi, ki ju je treba uporabiti v postopku pred pristojnim okrožnim sodiščem, ko sodišče odloča o razglasitvi izvršljivosti tujega izvršilnega naslova v Republiki Sloveniji oziroma v tistih primerih, ko ni predvidena eksekvatura, npr. ko sodišče odloča o predlogu za zavrnitev priznanja. Če je treba uporabiti uredbe, ki so navedene v 42b. členu ZIZ, se postopek priznanja in razglasitve izvršljivosti izvede pred pristojnim okrožnim sodiščem in o njem ne more odločiti izvršilno sodišče kot o predhodnem vprašanju. Poseben delibacijski postopek pred okrožnim sodiščem je tako pogoj, da lahko izvršilno sodišče s sklepom dovoli in opravi izvršbo. ${ }^{87}$ Razlikovati je tako treba med postopkom razglasitve izvršljivosti, ki vključi učinke tuje sodne odločbe v pravni red države izvršbe, in postopkom izvršbe, ki mu sledi. ${ }^{88}$ Ko je odločba vključena $v$ pravni red države članice EU, v kateri se zahteva izvršitev, se za izvršbo nato uporabljajo enaki predpisi kot za domače izvršilne naslove ${ }^{89}$ Ce je izvršitev tujega izvršilnega naslova predlagana v RS, mora izvršilno sodišče enako kot pri domačih izvršilnih naslovih pred dovolitvijo izvršbe preveriti primernost tujega izvršilnega naslova za izvršbo.

\subsection{Problematika ugotavljanja primernosti tujega izvršilnega naslova $\mathbf{R}$ RS}

Vrhovno sodišče RS je v zadevi II Ips 408/2003 ob odločanju o zahtevi za varstvo zakonitosti presojalo dolžnosti izvršilnega sodišča ob dovolitvi izvršbe ter ugotovilo, da mora vsako izvršilno sodišče ob odločanju o utemeljenosti predloga za izvršbo presojati, ali obstoji upnikovo materialno pravno upravičenje, dolžnikova obveznost, obstoj, veljavnost in zapadlost terjatve iz izvršilnega naslova ter

85 Uredba (EU) št. 1215/2012 Evropskega parlamenta in Sveta z dne 12. decembra 2012 o pristojnosti in priznavanju ter izvrševanju sodnih odločb v civilnih in gospodarskih zadevah (v nadaljevanju BU Ia).

${ }^{86}$ Uredba (EU) št. 606/2013 Evropskega parlamenta in Sveta z dne 12. junija 2013 o vzajemnem priznavanju zaščitnih ukrepov v civilnih zadevah.

87 Tako tudi VSL sklep II Ip 645/2019 z dne 9. 5. 2019.

88 (Sladič 2019, str. 18).

89 Glej tudi sodbo sodišča EU v zadevi Prism Investments, C-139/2010 z dne 13. 10. 2011 (ECLI:EU:C:2011:653). 
ustreznost sredstev in predmetov izvršbe. Vrhovno sodišče RS je tako zaključilo, da je izvršbo mogoče dovoliti in opraviti le v obsegu, kot izhaja iz izvršilnega naslova, izvršilno sodišče pa mora ob dovolitvi izvršbe po uradni dolžnosti paziti na obstoj in primernost izvršilnega naslova.$^{90}$ Navedeno velja tako pri dovolitvi izvršbe na podlagi domačega izvršilnega naslova kot tudi pri dovolitvi izvršbe na podlagi tujega izvršilnega naslova. Izvršba je namreč mogoča le, če izvršilni naslov vsebuje dovolj natančno opredelitev terjatve, torej opredelitev terjatve $v$ njenem subjektivnem in objektivnem smislu. ${ }^{91}$ Uporaba obveznih obrazcev, ki jih določajo evropske uredbe (po katerih več ni eksekvature), bi naj preprečevala, da tuje sodišče oziroma tuj organ potrdi nedoločen oziroma pomanjkljiv izvršilni naslov. $\mathrm{V}$ pripravljene obrazce je namreč treba zapisati nominalne podatke o terjatvi, njeni zapadlosti, glavnici, obrestih ${ }^{92}$ in stroških. Pri denarnih zahtevkih je treba zapisati tudi valuto obveznosti. Drugače je pri tistih izvršilnih naslovih, za katere je še vedno treba izvesti postopek priznanja in izvršitve. $\mathrm{V}$ teh primerih nimamo obrazca, iz katerega izhajajo natančnejši podatki o terjatvi, temveč le izvod tujega izvršilnega naslova ter sklep o eksekvaturi. $\mathbf{Z}$ vprašanjem primernosti tujega izvršilnega naslova za izvršbo se bo tako ukvarjalo šele izvršilno sodišče.

\subsubsection{Obrestni del zahtevka v tujem izvršilnem naslovu}

Ne glede na izvor tujega izvršilnega naslova prihaja v izvršilnem postopku do težav predvsem pri izvršitvi obrestnega dela zahtevka, kadar le-ta ni dovolj določen. Glede višine in teka obresti je slovensko izvršilno sodišče vezano na tuj izvršilni naslov, kar posledično pomeni, da če je obrestna mera zamudnih obresti določena po tuji zakonodaji, se izvrši pri nas po stopnji obrestne mere, kot jo določa tuja zakonodaja. ${ }^{93}$

Za vse v slovenskem izvršilnem postopku predložene tuje izvršilne naslove velja, da je treba vprašanja materialnopravne narave presojati po tujem pravu. Gre za vprašanja zapadlosti terjatve, obresti, zastaranja terjatve itd. Vsa vprašanja, ki so vezana na samo terjatev, ki izvira iz izvršilnega naslova, je treba presojati po tujem pravu. Slovensko izvršilno sodišče je namreč vezano na načelo formalne legalitete in zato je treba uporabiti pravo, ki ga je pri izdaji tujega izvršilnega naslova uporabilo tuje sodišče oziroma organ. ${ }^{44}$ Kadar je treba uporabiti tuje pravo, bo zaradi poizvedb o tuji zakonodaji izvršilni postopek upočasnjen.

\footnotetext{
VSRS sklep II Ips 408/2003 z dne 27. 11. 2003.

(Rijavec 2007b, str. 802).

Prav tam, str. 802.

93 Podrobno o izterjavi obresti v izvršilnem postopku v Republiki Sloveniji glej (Merc 2021, str.

94 Tako tudi VSL sklep I Ip 792/2019 z dne 23. 5. 2019.
} 69-90). 


\subsubsection{Terjatev $v$ tuji valuti}

Ob do sedaj izpostavljenih vprašanjih glede določenosti terjatve, vsebovane v izvršilnem naslovu, se postavlja tudi vprašanje, kako dovoliti izvršbo, če je denarna obveznost v izvršilnem naslovu sicer določno navedena, vendar je navedena v tuji valuti (valuti, ki ni evro). Ali je torej pravilno dovoliti izvršbo v tuji valuti brez preračunavanja $v$ evre na dan izdaje sklepa o izvršbi ali je pravilno ob izdaji sklepa (ali ob vložitvi predloga za izvršbo) opraviti preračun v domačo valuto (evre) $)^{95}$ ter ali ob realizaciji sklepa o izvršbi upnik na svoj račun prejme tujo ali domačo valuto. V slovenskem izvršilnem postopku so pogosti domači izvršilni naslovi, ki vsebujejo tujo valuto, neposredno izvršljivi notarski zapisi (kreditne pogodbe). Prav tako ni izključeno, da je tuja valuta kot valuta izpolnitve določena tudi v drugih domačih izvršilnih naslovih. Pri tujih izvršilnih naslovih velja podobno, da je lahko v tujem izvršilnem naslovu obveznost dolžnika določena $v$ domači valuti (evro) ali tuji valuti. $Z$ vprašanjem, kako dovoliti izvršbo, kadar gre za tujo valuto, se torej lahko izvršilno sodišče sreča tako pri domačih kot pri tujih izvršilnih naslovih.

V Republiki Sloveniji je zakonito plačilno sredstvo evro, ${ }^{96}$ vendar zgolj zaradi tega ni mogoče dovoliti izvršbe $v$ evrih, ${ }^{97}$ kadar iz izvršilnega naslova (bodisi domačega bodisi tujega) izhaja tuja valuta. Tudi v pravdi ni prepovedano postaviti tožbenega zahtevka $v$ tuji valuti. ${ }^{98}$ Bistveno je torej vprašanje, kako mora upnik oblikovati predlog za izvršbo, ali tako da zahteva glavnico v tuji valuti ali jo mora preračunati v evre. Sodna praksa ${ }^{99}$ je glede tega vprašanja neenotna. Večina slovenskih izvršilnih sodišč še vedno tipsko dovoljuje izvršbo (»sodišče dovoli izvršbo na podlagi predloga upnika $z$ dne ... «100 in le sledi upnikovemu predlogu za izvršbo, ki (še vedno velikokrat) preračuna terjatev v evre. Če dolžnik sklepu o izvršbi ne bo ugovarjal, se o vprašanju pravilne dovolitve izvršbe sploh ne bo razpravljalo. Novejša sodna praksa pa je oblikovala stališče, da je izvršbo mogoče dovoliti le za tisto terjatev, o kateri je bilo pravnomočno odločeno, torej za terjatev $\mathrm{v}$ tuji valuti. Noben zakon ne daje podlage, da bi bilo mogoče terjatev v tuji valuti spremeniti (preračunati) v evre v fazi dovolitve izvršbe. Pravilno in nenazadnje tudi v skladu $z$ načelom formalne legalitete je, da sodišče dovoli izvršbo za terjatev v tuji valuti. Upnik v izvršilnem postopku nima možnosti, da bi obveznost v tuji valuti, kot izhaja iz izvršilnega naslova, pretvoril v domačo valuto (torej evre) na trenutek vložitve predloga za izvršbo, saj bi s tem zahteval izvršbo za drugačno obveznost, kot izhaja iz izvršilnega naslova. ${ }^{101}$ Izvršilno sodišče mora biti

95 Glej podpoglavje 3.2. Valorizacija denarnih obveznosti.

96 3. člen Zakona o uvedbi eura (v nadaljevanju ZUE), Uradni list RS, št. 114/06.

97 VSL sklep I Ip 1366/2015 z dne 30. 9. 2015.

98 VSRS sodba III Ips 34/2005 z dne 13. 11. 2007 in VSL sodba I Cp 912/2012 z dne 7. 11. 2012.

99 Stališče, da je izvršbo treba dovoliti v domači valuti, je zavzelo VSK v sklepu II Cpg 121/2005 z dne 10. 11. 2005

100 Sodišče dovoli predlagano izvršbo, predlog upnika pa postane del sklepa o izvršbi, zato navedeno ne pomeni, da terjatev v izreku sklepa o izvršbi ni konkretizirana. Glej VSL sklep I Ip 792/2019 z dne 23. 5. 2019.

101 Glej VSM sklep I Ip 197/2017 z dne 30. 5. 2017 in VSM sklep I Ip 31/2018 z dne 1. 3. 2018. 
pri dovolitvi izvršbe zvesto izvršilnemu naslovu in mora odločati le o dopustnosti predlagane izvršbe za izterjavo že prisojenega zahtevka. Pred izvršilnim sodiščem ni dopustno postavljanje vprašanja, ali je denarna terjatev po sklepu o izvršbi enaka tisti, ki je bila določena $\mathrm{v}$ izvršilnem naslovu. ${ }^{102}$ Upoštevati je treba temeljno načelo izvršilnega postopka, tj. načelo formalne legalitete, zato mora biti denarni znesek naveden v predlogu za izvršbo enak znesku, ki izhaja iz izvršilnega naslova prav tako tudi valuta denarne obveznosti. OZ v 282. členu določa, da je izpolnitev izvršitev tistega, kar je vsebina obveznosti, zato je dolžnik niti ne more izpolniti s čim drugim, niti ne more upnik zahtevati kaj drugega. Valuta denarne obveznosti je tudi lahko bistvena lastnost predmeta obveznosti, zato mora dolžnik plačati tisto število denarnih enot, na katero se glasi obveznost (načelo monetarnega nominalizma). ${ }^{103}$

Tudi ZIZ nikjer ne določa, da sodišče ne bi smelo dovoliti izvršbe v tuji valuti. Edino mesto, kjer ZIZ govori o valuti, v kateri je treba izpolniti obveznost, je drugi odstavek 139. člena, kjer je določeno: „Če se terjatev iz izvršilnega naslova glasi na tujo valuto, sodišče na upnikov predlog dovoli izvršbo za poplačilo te terjatve $v$ tuji valuti $z$ dolžnikovih sredstev v tuji valuti. «Iz navedene določbe tako izhaja, da je izvršba v tuji valuti povsem dopustna. ${ }^{104}$ Pomembno je opozoriti, da je 139. člen ZIZ umeščen v poglavje, ki se nanaša na izvršbo na dolžnikova denarna sredstva pri organizacijah za plačilni promet, torej ne gre za splošno določbo, vendar je mogoče s pomočjo argumenta a simili ad simile ${ }^{105}$ sklepati, da se izvršba na denarno terjatev, ki je opredeljena v tuji valuti, dovoli v tuji valuti.

Glede oprave izvršbe v tuji valuti pa je glede na drugi odstavek 139. člena ZIZ mogoče sklepati, da kadar poteka izvršba na dolžnikova denarna sredstva pri organizacijah za plačilni promet, sama valutna pretvorba niti ni potrebna, saj se izvršba za obveznost v tuji valuti opravi neposredno iz dolžnikovih sredstev v tuji valuti, če le-ta obstajajo. ${ }^{106}$ Drugače je v primeru, če sredstev v tuji valuti na dolžnikovem računu ni ter $\mathrm{v}$ primerih oprave izvršbe $\mathrm{z}$ drugimi izvršilnimi sredstvi, npr. kadar gre za rubež premičnin, izvršba pa je dovoljena v tuji valuti. V takšni situaciji pa se lahko opravi izvršba za obveznost v tuji valuti le tako, da se opravi valutna pretvorba na dan plačila upniku. Če gre za izvršbo na denarna sredstva dolžnika pri organizaciji za plačilni promet, le-ta preračuna tujo valuto $\mathrm{v}$ evre po svojem nakupnem tečaju na dan plačila. ${ }^{107}$ Upnik prejme na svoj račun tujo valuto. Ker pa zakonodajalec ni uredil primera poplačila upnika v primerih, ko so predlagana druga izvršilna sredstva (npr. rubež premičnin), lahko s sklepanjem od podobnega na podobno navedeno pravno praznino zapolnimo tako, da izvrševalec sklepa o izvršbi (npr. izvršitelj) opravi preračun terjatve - iz tuje valute v domačo valuto. Pooblastilo izvršitelja, da opravi poplačilo upnika, izhaja iz 97. člena ZIZ,

102 VSL sklep I Ip 1366/2015 z dne 30. 9. 2015.

103 Glej 371. člen OZ in VSL sklep I Ip 1366/2015 z dne 30. 9. 2015. 2019.

104 Tako tudi VSL sklep I Ip 1366/2015 z dne 30. 9. 2015 in VSL sklep I Ip 1048/2019 z dne 5. 6.

105 »Sklepanje od podobnega na podobno«. Več o tem glej (Pavčnik 2013, str. 164-165).

106 Tako tudi VSM sklep I Ip 197/2017 z dne 30. 5. 2017.

107 Prvi odstavek 139. člena ZIZ. 
vendar pa navedena določba nikjer ne določa, po katerem tečaju naj izvršitelj opravi preračun terjatve, ki je opredeljena v tuji valuti. Postavi se vprašanje, ali lahko tudi v primerih oprave izvršbe z drugimi izvršilnimi sredstvi uporabimo določbo prvega odstavka 139. člena ZIZ o valutni pretvorbi po nakupnem tečaju neke konkretne banke. Glede na specialnost pravila, ki se nanaša le na izvršbo na denarna sredstva dolžnika pri organizacijah za plačilni promet, je zaključiti, da tega tečaja ni mogoče uporabiti na splošno. ${ }^{108}$ Banke imajo različne nakupne in prodajne tečaje, zato si izvršitelj ne more kar poljubno izbrati banke in njenega nakupnega (oziroma prodajnega) tečaja, temveč je pretvorbo valute na dan plačila treba opraviti glede na povprečje nakupnih in prodajnih tečajev različnih bank - torej po tečajnici Banke Slovenije, ki na dan plačila terjatve odraža tržne razmere. Iz tega razloga je smiselno in nujno, da se v sklepu o izvršbi posebej zapiše, da se bo na dan plačila opravila pretvorba valute po tečajnici Banke Slovenije (npr. dovoli se izvršba za izterjavo 1.000,00 HRK (hrvaških kun) v evro protivrednosti po tečajnici Banke Slovenije na dan plačila). Izrek sklepa o izvršbi je tako bolj jasen in odpravlja kasnejše težave pri pretvorbi valut. Nenazadnje pa tudi Zakon o deviznem poslovanju ${ }^{109} \mathrm{v}$ 7. členu določa, da se za izkazovanje podatkov pri poslovanju s tujino uporabljajo tečaji tečajnic Banke Slovenije. Tretji odstavek 139. člena ZIZ, ki določa, da terjatev v tuji valuti izplača organizacija za plačilni promet na način, ki ga določajo devizni predpisi, je prav tako v nasprotju s prvim odstavkom 139. člena ZIZ, ki za preračun tuje valute določa nakupni tečaj banke, zato bi bilo smiselno prvi odstavek 139. člena ZIZ spremeniti tako, da bi namesto nakupnega tečaja konkretne banke bilo zapisano, da se pretvorba tuje valute v evre opravi po tečajnici Banke Slovenije, saj bi bila tako odpravljena neskladja pri opravi izvršbe ne glede na sredstvo izvršbe. Prav tako bi zakonodajalec lahko splošne določbe ZIZ dopolnil tudi glede dovolitve (in dejanske oprave) izvršbe v tuji valuti.

Zaključiti je torej, da bi izvršilno sodišče ravnalo v nasprotju z načelom formalne legalitete, če bi za terjatev v tuji valuti (kot je določeno v izvršilnem naslovu) dovolilo izvršbo v evrih. Zato je smiselno, da izvršilno sodišče upnika, ki nepravilno predlaga izvršbo, pozove na popravo predloga za izvršbo tako, da terjatev iz izvršilnega naslova uskladi s terjatvijo, ki jo izterjuje v predlogu za izvršbo. ${ }^{110}$

Če je obveznost v tujem izvršilnem naslovu (npr. hrvaški sodbi) določena v tuji valuti (npr. hrvaških kunah) in želi upnik priti do poplačila svoje terjatve v Republiki Sloveniji, bo moral obveznost dolžnika v predlogu za izvršbo opredeliti v tuji valuti (torej v hrvaških kunah). Če dolžnik razpolaga le s sredstvi v domači valuti, se bo na dan oprave izvršbe opravila prisilna pretvorba dolžnikovih sredstev v domači valuti v tujo valuto (po tečajnici Banke Slovenije) in upnik bo na svoj račun prejel tujo valuto (hrvaške kune).

108 VSL je v sklepu I Ip 1048/2019 z dne 5. 6. 2019 je zavzelo stališče, da izvrševalec sklepa o izvršbi opravi preračun terjatve po prodajnem tečaju za ustrezno tujo valuto na dan plačila.

109 Zakon o deviznem poslovanju (v nadaljevanju ZDP-2), Uradni list RS, št. 16/08, 85/09, 109/12.

110 Praksa je tukaj sicer različna, od primera, da sodišče predlog za izvršbo zavrne, do primera, da sodišče dovoli izvršbo za terjatev v tuji valuti, čeprav je bila predlagana izvršba v evrih. 


\subsubsection{Primernost tujih notarskih zapisov}

Tuji notarski zapis, ki izvira iz države članice EU, je v skladu z Uredbo o EIN lahko potrjen kot evropski izvršilni naslov. Notar, ki potrdi notarsko listino kot evropski izvršilni naslov, preveri ali so izpolnjeni pogoji za izvršljivost notarskega zapisa, tj. dolžnikovo soglasje z neposredno izvršljivostjo in zapadlost terjatve. V državi izvršbe se zadržek javnega reda ne more več uveljavljati, ${ }^{111}$ lahko pa dolžnik ugovarja, da je bil notarski zapis v državi izvora s sodbo izrečen za ničnega.

Upnik lahko izvršbo na podlagi tujega notarskega zapisa predlaga bodisi z uporabo sistema o EIN bodisi se odloči za uporabo sistema, ki ga daje BU Ia. Ce notarski zapis, ki izvira iz države članice EU ni potrjen kot evropski izvršilni naslov oziroma nima priloženega potrdila o izvršljivosti po BU Ia $^{112}$ (oziroma po Uredbi 4/2009/ES), potem ne predstavlja izvršilnega naslova in izvršbe ni mogoče dovoliti. ${ }^{113}$ Če je bil notarski zapis, ki izhaja iz države članice EU, sklenjen pred 10. 1. 2015, in je treba uporabiti uredbo BU I, pa mora upnik sprožiti postopek za razglasitev izvršljivosti tujega notarskega zapisa v Republiki Sloveniji. ${ }^{114} \mathrm{Ne}$ glede na to, katero uredbo je treba uporabiti (Uredba o EIN, BU I, BU Ia, Uredba 4/2009/ ES), je vsem skupno, da se potrjuje isto dejstvo, to je izvršljivost. ${ }^{115}$

Kadar gre za notarski zapis, ki ne izhaja iz države članice EU, je treba uporabiti mednarodno pogodbo, ki velja med državama. V skladu z 8. členom Ustave RS se ratificirane in objavljene mednarodne pogodbe uporabljajo neposredno. Če takšna mednarodna pogodba med državama ne obstaja, se uporabi nacionalno pravo. Ker notarski zapis nima učinka pravnomočnosti, se ne uporabljajo določbe ZMZPP, ${ }^{116}$ temveč se uporabi Zakon o notariatu, ${ }^{117}$ ki za izvršitev tujega notarskega zapisa določa naslednje pogoje:

- da je podana vzajemnost, ${ }^{118}$

- da se nanaša na pravice, ki niso v nasprotju z javnim redom Republike Slovenije,

- da vsebuje vse elemente, ki so pogoj za izvršljivost po $\mathrm{ZN}^{119}$ (določena obveznost nekaj dati, storiti, opustiti ali trpeti, soglasje zavezanca za neposredno izvršljivost in zapadlost obveznosti). ${ }^{120}$ Navedeni pogoji morajo biti tako izpolnjeni, da se bo lahko tuj notarski zapis v Republiki Sloveniji

111 Več o notarskem zapisu kot evropskem izvršilnem naslovu glej (Rijavec 2017, str. 154-155).

112 Za notarske zapise je to potrdilo na Prilogi št. II.

113 Tako tudi VSC sklep I Ip 391/2011 z dne 12. 1. 2012.

114 Glej VSL sklep I Ip 3664/2017 z dne 10. 1. 2018.

115 (Rijavec 2017, str. 157).

116 94. člen ZMZPP in nadaljnji členi določajo le postopek priznanja in izvršitve tuje sodne odločbe, sodne poravnave oziroma odločbe drugega organa, ki je v državi, v kateri je izdana, izenačena s sodno odločbo oziroma sodno poravnavo, če ureja razmerja iz 1. člena ZMZPP.

117 V nadaljevanju ZN, Uradni list RS, št. 13/94, 48/94, 82/94, 41/95 - odl. US, 83/01 - OZ, 73/04, 98/05, 17/06 - ZIZ-C, 115/06, 33/07 - ZSReg-B, 45/08, 91/13, 36/20 - ZZUSUDJZ.

118 Prvi odstavek 7. člena ZN določa: »Ob pogoju vzajemnosti ima notarska listina izdana $v$ tuji državi v RS enako pravno veljavo kot notarska listina izdana po tem zakonu.«

119 Glej drugi odstavek 7. člena ZN.

120 Več o izvršitvi tujega notarskega zapisa po pravu RS glej (Rijavec 2008a, str. 1007-1008). 
izvršil. Če pravna pravila tuje države onemogočajo priznanje in izvršitev slovenskih notarskih zapisov (ni izpolnjen pogoj vzajemnosti), se predlog za izvršbo zavrne. Prav tako se predlog za izvršbo zavrne, če izvršilno sodišče po uradni dolžnosti ugotovi, da gre za zadržek javnega reda.

Za izvršitev tujega notarskega zapisa, ki izvira iz tretje države, ${ }^{121}$ se predhodno ne izvede postopek priznanja in razglasitve izvršljivosti pred pristojnim okrožnim sodiščem, saj se ta postopek izvede le v primeru uporabe ZMZPP. Izvršilno sodišče tako ob dovolitvi izvršbe samo presoja, ali ima tuj notarski zapis vse elemente (ustreznost soglasja, zapadlost terjatve, itd.). O priznanju tujega notarskega zapisa tako odloča kot o predhodnem vprašanju. ${ }^{122}$ Postavlja se vprašanje, po katerem pravu je treba presojati ustreznost takšnega notarskega zapisa. Zaradi načela formalne legalitete (vezanosti na izvršilni naslov) je zaključiti, da je vprašanja materialnopravne narave treba presojati po tujem pravu (npr. zapadlost terjatve), ${ }^{123}$ vprašanja procesne narave pa po slovenskem pravu. Postopek izvršbe je namreč treba izvesti v skladu s pravili ZIZ. Pri notarskih zapisih iz tretjih držav je treba paziti, da vsebina izvršitve obveznosti iz notarskega zapisa ne nasprotuje slovenskemu javnemu redu.

Ne glede na izvor tujega notarskega zapisa pa je ob dovolitvi izvršbe treba vedno paziti, da je notarski zapis primeren za izvršbo, torej da so v njem navedeni upnik in dolžnik ter predmet, vrsta obseg in čas izpolnitve obveznosti. Presoditi je treba, ali bo obveznost iz notarskega zapisa v Republiki Sloveniji mogoče izvršiti. Pogoj za izvršljivost tujega notarskega zapisa je torej tudi, da je obveznost v njem določena oziroma določljiva. ${ }^{124}$ Tuj notarski zapis lahko vsebuje določila o obrestih, ki niso v skladu s slovensko zakonodajo oziroma prisilnimi predpisi. V takem primeru se izvršilno sodišče ne sme spuščati v presojo, ali so obresti, ki izhajajo iz tujega notarskega zapisa po slovenskem pravu dovoljene, temveč mora dovoliti izvršbo. Gre namreč za vprašanje materialnega prava, ki se presoja po pravu države, v kateri je bila notarska listina sestavljena.

\subsection{Primerjalno pravne ugotovitve glede presoje vsebine tujih izvršilnih naslovov}

\subsubsection{Primerjava z Republiko Hrvaško}

Enako kot slovenski pravni sistem, tudi pravo Republike Hrvaške pozna načelo stroge formalne legalitete (22. člen hrOZ), zato lahko hrvaško sodišče dovoli izvršbo le v obsegu, kot izhaja iz izvršilnega naslova, ${ }^{125}$ ter ne sme preverjati zakonitosti

121 Država, ki ni članica EU in je uredbe ne zavezujejo.

122 (Rijavec 2003, str. 128).

123 (Rijavec 2008a, str. 1008).

124 O tem glej tudi (Dolžan 2012, str. 335).

125 Glej odločbo Županijskega suda u Varaždinu, Gž Ovr-391/17-2 z dne 26. 4. 2017 in odločbo Županijskega suda u Splitu, Gž Ovr 316/2016-1 z dne 19. 5. 2016. 
postopka, iz katerega izhaja izvršilni naslov, prav tako tudi ne materialnopravne pravilnosti samega izvršilnega naslova. ${ }^{126}$ Načelo formalne legalitete velja tako za domače kot tuje izvršilne naslove, ${ }^{127}$ pri čemer hrOZ našteva tuje izvršilne naslove $\mathrm{v}$ 19. členu, domače izvršilne naslove pa v 23. členu. Postopek na podlagi evropskega izvršilnega naslova pa je posebej urejen, in sicer v členih od 356. do 364. hrOZ.

O tuji valuti hrOZ govori le na enem mestu, in sicer tretji odstavek 301. člena določa, da je terjatev, ki se zavaruje, lahko izražena tudi v kunski protivrednosti, ki ustreza določenemu znesku v tuji valuti. HrOZ pa ne vsebuje pravila, ki bi določalo, kako dovolitvi izvršbo, kadar gre za tuj izvršilni naslov. Na podlagi sprejetih stališč, ki jih je izoblikovala hrvaška sodna praksa, je mogoče zaključiti, da kadar je glavna terjatev v tujem izvršilnem naslovu opredeljena v tuji valuti (npr. v EUR), se v Republiki Hrvaški izvršba dovoli tako, da se glavnica zapiše v tuji valuti (torej $\mathrm{v}$ EUR) $\mathbf{s}$ pripisom $\mathbf{v}$ protivrednosti $\mathbf{v}$ hrvaških kunah po srednjem tečaju Hrvaške narodne banke na dan plačila. ${ }^{128}$ Glede obrestnega dela zahtevka pa je tudi hrvaška sodna praksa sprejela stališče, da je treba izvršbo za zamudne obresti dovoliti po stopnji obrestne mere, kot jo določa konkretni izvršilni naslov (če tuj izvršilni naslov izvira iz Bosne in Hercegovine - $\mathrm{BiH}$, upniku pripadajo zamudne obresti po stopnji, kot je določena s predpisi BiH). ${ }^{129}$ Pravica do zaračunavanja obresti namreč ne izhaja iz samega zakona, temveč mora izhajati iz izvršilnega naslova. ${ }^{130}$ Pri vložitvi predloga za izvršbo na podlagi tujega izvršilnega naslova mora upnik paziti, da bo predlog za izvršbo dovolj določen, jasen in natančen ter popolnoma skladen $\mathrm{z}$ izvršilnim naslovom. ${ }^{131} \mathrm{Na}$ podlagi navedenega je torej zaključiti, da tudi na Hrvaškem velja, da je stopnja obrestne mere zamudnih obresti vezana na sam izvršilni naslov, na podlagi katerega upnik poda predlog za izvršbo.

\subsubsection{Primerjava z Republiko Avstrijo}

V pravnem redu Republike Avstrije velja, da mora biti denarni znesek, ki se izterjuje, v izvršilnem naslovu vedno določen tako, da je številčno opredeljen, brez potrebe po nadaljnjem pravnem ali dejanskem sklepanju. ${ }^{132}$ Navedeno velja tako za domače kot tuje izvršilne naslove, ki so predloženi v izvršilnem postopku. Vrhovno sodišče Republike Avstrije je v zadevah v zvezi z izvršitvijo tujih izvršilnih naslovov odločilo, da je pogoj za razglasitev izvršljivosti tujih izvršilnih naslovov njihova določnost. Vendar se za določnost tujih izvršilnih naslovov ne smejo postavljati enake zahteve kot za domače izvršilne naslove. Zlasti pri evropskih izvršilnih

126 (Dika 2007, str. 54) in odločba Županijskega suda u Splitu, Gžovr 1872/2016-2 z dne 16. 12. 2016 ter odločba Županijskega suda u Velikoj Gorici, Gž Ovr 21/2016-2 z dne 6. 4. 2016.

127 Županijski sud u Splitu, odločba Gž Ovr 818/2016-1 z dne 25. 5. 2016.

128 Glej odločbi Županijskih sudova, Gž Ovr 514/2017-2 z dne 27. 2. 2018 (Zadar) in Gž Ovr 552/2017-2 z dne 22. 9. 2017 (Pula).

129 Županijski sud u Zadru, odločba Gž Ovr 514/2017-2 z dne 27. 2. 2018.

130 Županijski sud u Bjelovaru, odločba ŽS Bj Gž 1360/2017 z dne 1. 1. 1997.

131 Županijski sud u Splitu, odločba Gž Ovr 1849/2016-2 z dne 13. 2. 2017.

132 (Neumayr and Nunner-Krautgasser 2018, str. 66). 
naslovih se ne sme preizkušati določnosti izvršilnega naslova, če je izvršilni naslov izvršljiv v državi članici izvora. ${ }^{133}$ Prav tako se pri uveljavljanju terjatve iz tujega izvršilnega naslova ne more iti tako daleč, da bi bil tuji izvršilni naslov učinkovitejši v državi izvršbe kot v državi izvora. ${ }^{134}$

Glede pretvorbe terjatve, ki se v izvršilnem naslovu glasi na tujo valuto, ${ }^{135}$ je Vrhovno sodišče Republike Avstrije sprejelo stališče, da je v primerih, kadar v izvršilnem naslovu ni klavzule, po kateri bi bila stranka dolžna plačati dolg v tuji valuti, treba plačilo opraviti v domači valuti. Pretvorbo iz tuje valute v domačo valuto je treba opraviti na dan plačila, ${ }^{136}$ zato je odločilen menjalni tečaj na dan plačila. ${ }^{137}$ $\mathrm{V}$ primeru prisilne ustanovitve zastavne pravice in prisilne dražbe nepremičnin dovolitev izvršbe $v$ tuji valuti ni dopustna, saj zaradi določbe $\S 5 / 31$. Euro$\mathrm{JuBeG}^{138}$ v Republiki Avstriji niso dopustni vnosi tujih valut v zemljiško knjigo. Zato je $\mathrm{v}$ teh primerih naloga upnika, da opravi pretvorbo tuje valute $\mathrm{v}$ domačo valuto že v predlogu za izvršbo. ${ }^{139} \mathrm{~V}$ takem primeru je odločilen menjalni tečaj pred vložitvijo predloga za izvršbo. ${ }^{140}$ Pri dovolitvi izvršbe na podlagi izvršilnega naslova, ki vsebuje tujo valuto, se torej upnikov zahtevek načeloma navede v tuji valuti, pretvorba pa se izvede po času in menjalnem tečaju dejanskega plačila. ${ }^{141}$

Tudi v avstrijskem pravnem redu velja, da morajo biti obresti določene. Navedeno izhaja neposredno iz $\S 7 / 1$ EO. Obresti so določene tako, da je navedena obrestna mera in datum začetka teka obresti. Sklep o dovolitvi izvršbe mora v skladu s $\S 63$ EO med drugim vsebovati izvršljiv zahtevek s podrobnostmi o vsebini in predmetu obveznosti kot tudi vse stranske terjatve. V primeru obrestnih terjatev je treba navesti obrestno mero in datum, od kdaj tečejo obresti. Če gre za spremenljive obresti, se odstotek obrestne mere navede samo, če je bil ugotovljen. ${ }^{142}$ Zahteva po določenosti obresti je tako izpolnjena le, če je čas teka obresti koledarsko določen, prav tako opozorilo na ustrezne zakonske določbe ni dovolj. ${ }^{143}$ Izjemo od določenosti obrestnega dela zahtevka ( $§ 7 / 1 \mathrm{EO})$ predstavlja $\S 8 \mathrm{a} E O,{ }^{144}$ po katerem se lahko izvršba dovoli tudi za obresti, ki so določene tako, da je obrestna mera oblikovana $\mathrm{v}$ določenem številu odstotnih točk nad osnovno obrestno mero. ${ }^{145}$

133 OGH 3Ob104/03w z dne 28. 1. 2004

134 OGH 3Ob98/03p z dne 21. 8. 2003.

135 T. i. »Fremdwährungstitel «.

136 OGH 3 Ob 161/09m z dne 30. 9. 2009.

137 OGH 3Ob11/91 z dne 10. 4. 1991 in Jakusch v (Angst and Oberhammer 2015, str. 94).

138 Euro-Justiz-Begleitgesetz, BGB1. 1998/125, v katerem so urejeni ukrepi zaradi uvedbe evra v Republiki Avstriji.

139 Jakusch v (Angst and Oberhammer 2015, str. 94).

140 OGH 3 Ob 98/06t z dne 30. 5. 2006.

141 Jakusch v (Angst and Oberhammer 2015, str. 94).

142 2. točka $\S 63 \mathrm{EO}$.

143 Jakusch v (Angst and Oberhammer 2015, str. 93).

144 § 8a EO: „Die Exekution ist bezüglich der Zinsen auch dann zu bewilligen, wenn der Zinssatz in einer bestimmten Zahl von Prozentpunkten über dem Basiszinssatz ausgedrückt wird. Eines Nachweises des Basiszinssatzes bedarf es nicht."

145 Jakusch v (Angst and Oberhammer 2015, str. 93). 
Avstrijska literatura in sodna praksa načela stroge formalne legalitete ne omenjata, vendar na splošno velja, da je treba izvršiti tisto, za kar je bil dolžnik v izvršilnem naslovu zavezan. ${ }^{146}$ Predlog za izvršbo in dovolitev izvršbe ne smeta presegati vsebine in obsega, ki izhaja iz izvršilnega naslova. Izjemo določa $\S$ 54a/2 ZPO, ki dovoljuje izvršbo za obresti, ki ne izhajajo iz izvršilnega naslova. ${ }^{147}$ Vrhovno sodišče Republike Avstrije je sprejelo stališče, da je izvršilno sodišče pri odločanju o predlogu za izvršbo vezano na potrdilo o izvršljivosti (die Vollst reckbarkeitsbestätigung). ${ }^{148}$ Potrdilo o izvršljivosti namreč zavezuje vsa sodišča. Izvršilno sodišče ob odločanju o dovolitvi izvršbe tudi ne sme preverjati pravilnosti potrdila o izvršljivosti, temveč je nanj vezano, dokler ni v skladu s tretjim ali četrtim odstavkom § 7 EO razveljavljeno. ${ }^{149}$ Iz navedenega je zaključiti, da avstrijski pravni red pozna pojem »vezanost na potrdilo o izvršljivosti«, ne pa pojma »vezanost na izvršilni naslov «. Izvršilno sodišče v Republiki Avstriji pri dovolitvi izvršbe ni vedno popolnoma vezano na vsebino izvršilnega naslova, saj je izrecno v zakonu zapisano, kdaj sodišče dovoli izvršbo za obresti, kadar le-te ne izhajajo izrecno iz izvršilnega naslova (§ 54a ZPO). Navedena izjema pa velja le za domače izvršilne naslove. ${ }^{150}$ Zaključimo lahko, da je tudi avstrijsko izvršilno sodišče pri izvršitvi obveznosti iz tujega izvršilnega naslova vezano na vsebino tujega izvršilnega naslova in mora izvršbo dovoliti, kot izhaja iz izreka tujega izvršilnega naslova.

\section{ZAKLJUČEK}

Ugotovili smo, da je za nemoten potek izvršbe nujno potrebno, da je obveznost v izvršilnem naslovu določno ali vsaj določljivo opredeljena. Obveznost je dovolj določno opredeljena, kadar že iz samega izreka izvršilnega naslova izhajajo vsi podatki, na podlagi katerih je obveznost mogoče natančneje določiti. Kadar je obveznost dovolj določno opredeljena, pravimo, da je izvršilni naslov primeren za izvršbo. Presoja primernosti izvršilnega naslova za izvršbo od izvršilnega sodišča ne sme terjati dodatnega vsebinskega odločanja. Izvršilno sodišče v fazi dovolitve izvršbe presoja primernost tako domačih kot tudi tujih izvršilnih naslovov.

Zaključimo lahko, da je izvršilni naslov primeren za izvršbo, kadar je vsem udeležencem izvršilnega postopka (sodišču, izvršitelju, banki) jasno, kaj je treba izvršiti oziroma kolikšna je točna višina denarnega zahtevka upnika. Kadar obveznost ne izhaja direktno iz izreka sodne odločbe, je dopustno, da se izrek sklicuje na priložen seznam ali npr. skico poti. Samo določno navedena obveznost v izvršilnem naslovu vodi do hitre in učinkovite izvršbe.

\footnotetext{
146 Jakusch v (Angst and Oberhammer 2015, str. 81).

147 (Neumayr and Nunner-Krautgasser 2018, str. 66).

148 OGH 3 Ob 189/10f $\mathrm{z}$ dne 14. 12. 2010.

149 Jakusch v (Angst and Oberhammer 2015, str. 110) in OGH 3 Ob 82/04m z dne 21. 7. 2004.

150 Več o tem (Merc 2021, str. 87).
} 


\section{LITERATURA}

1. Angst, Peter, and Paul Oberhammer. 2015. „Kommentar zur Exekutionsordnung.“ XXXVII, 2168 str. (Wien: Manz).

2. Dika, Mihajlo. 2007. Građansko ovršno pravo (Zagreb: Narodne novine).

3. Dolžan, Judita. 2012. 'Tuje javne listine in njihova veljava v Republiki Sloveniji', Podjetje in delo, 38: str. 332-44.

4. Galič, Aleš. 2006. 'Postopek priznanja in razglasitve izvršljivosti tujih sodnih odločb po uredbi št. 44/2001 (Bruseljski uredbi)', Zbornik znanstvenih razprav, 66: str. 6989.

5. Kogej Dmitrovič, Biserka. 2019. "Plačilo za delo.” In Aktualna vprašanja delovnega prava: "povezujemo teorijo s prakso": strokovna delavnica, Moravske Toplice, 12. in 13. april 2019, 89 str.

6. Merc, Irena. 2015a. '(Ne)določenost izvršilnega naslova', Podjetje in delo, 41: str. 596-612.

7. Merc, Irena. 2021. 'Recovery of Interest in Enforcement Procedure in the Republic of Slovenia', LeXonomica, 13: str. 69-90.

8. Neumayr, Matthias, and Bettina Nunner-Krautgasser. 2018. Exekutionsrecht (Wien: Manz).

9. Orož, Damjan. 2010. ,Aktualni problemi izvršilnega prava - izvršilni naslov‘, Pravosodni bilten, 31: str. 91-100.

10. Pavčnik, Marijan. 2013. Argumentacija v pravu: od življenjskega primera do pravne odločitve (Ljubljana: GV založba).

11. Plavšak, Nina in drugi. 2003. „Obligacijski zakonik (OZ): s komentarjem, 2. knjiga.“ (Ljubljana: GV založba).

12. Plavšak, Nina, Miha Juhart, and Renato Vrenčur. 2009. Obligacijsko pravo: splošni del (Ljubljana: GV založba).

13. Plavšak, Nina. 2012. 'Neposredna izvršljivost notarskega zapisa', Podjetje in delo, 38: str. 1617-1669.

14. Pustovrh Pirnat, Tanja. 2009. 'Izvršljivost sodnih odločb v individualnih delovnih sporih', Podjetje in delo, 35: str. 969-985.

15. Rijavec, Vesna. 2003. Civilno izvršilno pravo (GV založba: Ljubljana).

16. Rijavec, Vesna. 2007b. ,Postopek potrditve Evropskega izvršilnega naslova', Podjetje in delo, 33: str. 791-814.

17. Rijavec, Vesna. 2008a. „Izvršba na podlagi tujega izvršilnega naslova.“ In Dnevi slovenskih pravnikov 2008 od 16. do 18. oktobra, Portorož, str. 993-1009 (Ljubljana: GV Založba).

18. Rijavec, Vesna. 2017. „Javnobilježnički akt u medunarodnom pravnom prometu.“ In Zbornik radova s III. međunarodnog savjetovanja „Aktualnosti građanskog procesnog prava - nacionalna i usporedna pravnoteorijska i praktična dostignuća“, 26. $i$ 27. listopada 2017. godine, str. 151-162 (Split: Pravni fakultet).

19. Robnik, Ivan. 2010.,Oblikovanje zahtevkov in izrekov sodnih odločb v delovnih in socialnih sporih', Pravosodni bilten, 31: str. 113-123. 
20. Robnik, Ivan. 2018. ,Delovni spor o plačilu prejemkov iz delovnega razmerja“, Pravna praksa, 37: str. 6-7.

21. Sajovic, Rudolf. 1944. „Izvršilni postopnik: tolmač k zakonu o izvršbi in zavarovanju.“ XII, 560 str. (Ljubljana: Pravnik).

22. Sever Mlinarič, Špelca. 2017. ,Dileme delavcev in njihovih pooblaščencev glede tožbe na plačilo plače in s tem povezane izvršbe sodb delovnega sodišča', Pravosodni bilten, 38: str. 187-205.

23. Sladič, Jorg. 2019. ,Poenostavljena prisilna poravnava in izvršitev slovenske sodne odločbe v Avstriji“, Pravna praksa, 38: str. 16-18.

24. Triva, Siniša, Velimir Belajec, and Mihajlo Dika. 1984. Sudsko izvršno pravo: opći dio (Zagreb: Informator).

25. Ude, Lojze, Nina Betetto, Aleš Galič, Vesna Rijavec, Dragica Wedam-Lukić, and Jan Zobec. 2005-2010. „Pravdni postopek: zakon s komentarjem.“ 4 zv. 598; 670; 774; 350 str. (Ljubljana: Uradni list Republike Slovenije; GV založba).

26. Volk, Dida. 2000. Izvršba in zavarovanje: [izvršilni postopek in postopek zavarovanja, sodna praksa, vzorci predlogov] (Ljubljana: Odin).

\section{SUITABILITY OF THE ENFORCEMENT ORDER FOR ENFORCEMENT DOING}

The suitability of an enforcement title for enforcement is a substantive prerequisite for the Slovenian court's permission of execution. The claim to be recovered from a debtor must be in an enforcement title already sufficiently determined or at least determinable, otherwise enforcement cannot be allowed. Determinability of a debt means that all data on the basis of which a claim can be determined must already derive from the very operative part of the court's decision or from another enforceable title. The court in the enforcement procedure may not itself determine the meaning and the scope of the claim arising from the title. In the case of non-monetary claims in particular, it is important that they are clearly defined and that they leave no doubt as to what has to be done to meet the obligation. When a creditor proposes enforcement on the ground of a recognised and enforceable foreign title, the enforcement court is again bound by the principle of formal legality and can permit the enforcement only if the claim arising from the title is sufficiently defined.

Key words: enforcement procedure in the Republic of Slovenia, suitability of the enforcement title, principle of formal legality, determinability of the claim, determinable claim, foreign enforcement title 